\title{
STAGGERED PRICE AND WAGE SETTING IN MACROECONOMICS
}

\author{
John B. Taylor
}

Working Paper 6754

http://www.nber.org/papers/w6754

\author{
NATIONAL BUREAU OF ECONOMIC RESEARCH \\ 1050 Massachusetts Avenue \\ Cambridge, MA 02138 \\ October 1998
}

This research was supported by the Center for Economic Policy Research at Stanford University. I wish to thank V.V. Chari, Christopher Erceg, Robert Hall, Ellen McGrattan, Akila Weerapana, and Michael Woodford for useful comments and assistance. The views expressed here are those of the author and do not reflect those of the National Bureau of Economic Research.

(C) 1998 by John B. Taylor. All rights reserved. Short sections of text, not to exceed two paragraphs, may be quoted without explicit permission provided that full credit, including $\mathbb{C}$ notice, is given to the source. 
Staggered Price and Wage Setting

in Macroeconomics

John B. Taylor

NBER Working Paper No. 6754

October 1998

JEI No. E2, E10

\begin{abstract}
This paper reviews the role of temporary price and wage rigidities in explaining the dynamic relationship between money, real output, and inflation. It summarizes microeconomic data on price and wage setting behavior, and argues that staggered price and wage setting models provide the most satisfactory match with the data.

Research in this area has been very active in the 1990's with a remarkable number of studies using, estimating, or testing models of staggered price and wage setting. A new generation of econometric models incorporating staggered price and wage setting with rational expectations has been built. Researchers have begun to incorporate staggered wage and price setting into real business cycle models. Close links have been discovered between the parameters of people's utility functions and the parameters of price and wage setting equations. There is now a debate about whether standard calibrations of utility functions prevent staggered price models, at least those with frequent price changes, from explaining long persistence of real output. There is much to be discovered from these debates and from the future research they stimulate.
\end{abstract}

John B. Taylor

Department of Economics

Stanford University

Stanford, CA 93405-6072

and NBER

johntayl@leland.stanford.edu 


\section{Introduction}

Why does a change in the money supply cause real output and employment to change in the short run, but not in the long run? This is one of the oldest questions in macroeconomics, yet it persists as both the most difficult and the most practical of all. From David Hume in the 18th century to Milton Friedman in the 20th, economists have had a common answer: there are temporary price and wage rigidities in the economy. In other words, in the short run, price and/or wage levels do not change as much as the money supply changes. Thus, if the money supply increases, then real money balances rise, stimulating production and employment. As described by David Hume more than 200 years ago, "by degree the price rises, first of one commodity, then of another, " or as stated more recently by Milton Friedman "prices are sticky" (see Rotwein (1955, p. 38) and Friedman (1982, p. 64)). Except in unusual circumstances, it takes time for price and wage levels to fully adjust; as prices and wages gradually rise, real money balances return to their original level and in the long run the real economy is unaffected.

The purpose of this chapter is to review the current state of knowledge about the nature of price and wage rigidities and their ability to explain the dynamic relationship between money, real output, and inflation. I survey recent research, classify the major facts and models, and draw some conclusions and 
suggestions for future research. Because both price rigidities and wage rigidities are important for macroeconomic dynamics, both types of rigidities are reviewed.

The dynamic stochastic properties of money, output, and inflation that we would like the theories to explain have been carefully documented using modern time series techniques in the chapters by Stock and Watson (1998) and by Christiano, Eichenbaum, and Evans (1998) in this Handbook. In addition to the property that money shocks have a short-run impact on output and a long-run impact on inflation, three other important properties of the money, real output, and inflation relation have attracted attention. These properties are (1) that a monetary shock has a persistent effect on real output-a propagation effect that lasts well beyond the initial impact effect of a monetary shock, (2) that there is a positive correlation between real output and future inflation, and (3) that there is a negative correlation between inflation and future real output. (See Stock and Watson (1998), Table 2, lines 41 and 54, and Christiano, Eichenbaum and Evans (1998), Figures 2 and 3, which compare the impact of alternative measures of money shocks). Properties (2) and (3) can also be characterized using vector autoregressions and the concept of Granger-causality: property (2) is that real output Granger-causes inflation positively and property (3) is that inflation Granger-causes real output negatively. This "reverse 
dynamic" cross correlation was shown to hold in the United States and other countries in Taylor (1980a, 1986). The ability to explain such robust findings represents an important measure of success for any theory of price and wage rigidities.

It was in the early 1970 s that the rational expectations revolution in macroeconomics first began to take hold. Of course, price and wage rigidities were a big part of macroeconomics before the early 1970s; indeed, they were central to both Keynesian and monetarist ideas. However, by forcing macroeconomists to think in economy-wide (general equilibrium) terms, the rational expectations revolution fundamentally changed how economists model price and wage rigidities. It was at this time that the staggered contracts model was first proposed. This model emphasizes the overlapping of individual prices and wages due to staggered price and wage setting. It could explain not only why changes in money impact real output, but also why the other properties mentioned above are found to hold in many countries. From the start the staggered contract model was explicit enough that testable hypotheses could be formulated and, as a result, the model underwent extensive empirical and theoretical scrutiny, generating much debate. This explicitness was necessitated, in my view, by the discipline of the rational expectations approach to modeling.

During the 1980 s, researchers extended and modified 
models of staggered price and wage setting, fitted them to data from many different countries, and began to give them a more specific theoretical footing. Models of staggered price and wage setting were frequently used as a source of monetary nonneutrality in rational expectations policy studies of monetary policy rules. By using these theories of price and wage rigidities for policy analysis and by confronting them with practical tests using real world data--both microeconomic and macroeconomic-much has been learned about the process of wage and price formation in market economies.

In the 1990s research on staggered price and wage setting has showed no signs of slowing down. Modifications motivated by a need to explain inflation dynamics more accurately or to reduce model complexity have been introduced and used in econometric models. A new generation of econometric models incorporating price and wage rigidities with rational expectations has been put in place for policy analysis at many central banks including the Federal Reserve Board. Perhaps even more exciting, researchers have begun to incorporate theories of staggered wage and price setting into what would otherwise be real business cycle models. This research has uncovered close links between the parameters of people's utility functions or firm's production functions and the parameters of staggered price and wage setting equations. The research has also uncovered a 
puzzle: in some models, standard calibration of utility function parameters indicates substantially less persistence of real output than had been found in earlier estimates of staggered contract models that had not made this formal link to individual utility maximization. Several ways to resolve this puzzle have been proposed and are discussed here. On balance, the staggered wage and price setting models still seem to be consistent with the broad features of the data, but there is much to be discovered in future research. With the price and wage setting theories so amenable to empirical testing, it is not surprising that controversies and debates about price and wage rigidities continue.

I begin the chapter with a short guide to price and wage setting behavior in market economies based on direct and indirect observations. I then review alternative price and wage setting models and show how models based on staggered price and wage setting match the facts mentioned above, a match that explains, in my view, why the models have proved useful to macroeconomists doing applied econometrics and policy work. I then go on to explore the microeconomic foundations for these models, discussing several intriguing puzzles and their possible resolutions. Finally, I discuss several historical and policy applications of econometric models based on staggered price and wage setting.

As research on staggered price and wage setting has 
developed, several surveys of research on price and wage rigidities have appeared, including Taylor (1985), Blanchard (1990), Roberts (1995), and Goodfriend and King (1997), as well as several good graduate textbook treatments including Blanchard and Fischer (1989, Chapter 8) and Romer (1996, Chapter 6). In this survey I try to focus on topics that are either more recent or that have not been emphasized in these other surveys and reviews. I also try to trace out the gradual evolution of the staggered contracts model over time.

\section{An Empirical Guide to Price and Wage Setting in Market Economies}

Hume's theoretical idea--that slow price adjustment provides an explanation for the short run impact of changes in money on production--was based on his observations of price changes in the market economy in which he lived. Thanks to research in recent years we now have much more quantitative information about the timing, frequency, and determinants of price and wage changes.

\subsection{General Observations About Wage and Price Setting}

Before discussing this quantitative evidence, $I$ think it is useful to first review some general observations about wage and price setting which are simply part of our everyday experience as 
participants in market economies. One might criticize these types of observations as arbitrary and subjective, but in fact such informal case studies have informed the theoretical research in this area much as David Hume's casual observations informed his theory.

\section{Wage Setting}

One observes a great variety of ways in which wages are determined through the interaction of workers and firms in a market economy. These mechanisms evolve over time especially when there are large changes in the economic environment such as a change in the tax law or a rise in the average rate of inflation. There are, however, some important common features of these wage setting arrangements.

For most workers employed in medium to large sized firms, wages (including benefits) are normally adjusted at rather long discrete intervals, most commonly once per year. The wage adjustment is typically associated with an extensive performance and salary review. A large fraction of the wage payment is usually stated in a fixed amount of dollars (or other currency) per unit of time (hour, week or month), but overtime pay, bonuses, profit sharing, piece rates, and other incentive arrangements are not uncommon for part of workers' pay. Indexing of wages to macroeconomic variables, such as the inflation rate, occurs, but 
is rare in wage setting arrangements of one year or less.

It is important to emphasize that setting nominal wages at a fixed level for more than several quarters and usually for as long as a year appears to be just as prevalent for workers who are not in unions, or who do not have formal employment contracts, as for union workers with employment contracts. It is a mistake to limit studies of how wages are set to formal employment contracts. As we will see below there is more quantitative information about indexing and contract length for workers and firms in the union sectors, but in the United States only a relatively small fraction of workers are in unions, so the evidence is less relevant.

Throughout the economy wage setting is not usually synchronized in any one period. Rather wage adjustments occur at different times for different firms throughout the year, much as the dates for firms' fiscal years vary throughout the year. There are exceptions to this nonsynchronization. In Japan, for example, there has been a Shunto, or spring offensive, during which wages at most large firms are set.

Wage decisions are clearly influenced by wages paid to other workers in a community or in similar occupations. When hiring new engineers or business school graduates, firms must consider the prevailing wage in the market for similarly educated workers when designing a wage package. Pattern bargaining 
among labor unions where the wage set at one union becomes a strong influence at another union is common.

\section{Price Setting}

There are even greater varieties of price setting than of wage setting. Prices change continuously in auction markets for commodities and financial instruments. The idea of price rigidities seems ludicrous when applied to such markets.

On the other hand, prices change infrequently in postedprice customer markets for goods and services. (Okun (1981) used the term "customer markets" to distinguish these types of markets from "auction markets.") Prices of final goods in customer markets seem to be more responsive to changes in the costs of intermediate inputs to production than they are to changes in demand. In other words, changes in markups seem less of a source of price change than changes in costs. But even within socalled customer markets, prices--and markups of prices over costs--can and do change rapidly. For example, the price of airline tickets changes on a day to day basis depending on estimates of demand. Some airline tickets are now even auctioned on the internet.

Like wages, the prices of goods and services appear to be staggered over time and set taking the prevailing price of competing producers (or monopolistically competing producers) 
into account. News accounts suggest, for example, that a decision to change the price of Big Macs is closely watched by Burger King and other fast food companies. Case studies of pricing at large supermarket chains by Levy, Dutta, Bergen, and Venable (1998) show that obtaining information about the prices of competitors is the first step in deciding on how much to change prices; they find that "people are sent on a weekly basis to competitors' stores to gather and record (usually by hand) their price..." Clearly some degree of non-synchronized or staggered price setting is necessary if such surveys of competitors' prices are to be useful. The policy of matching a competitor's price is common among discount stores. The prevailing price is even an important consideration in price setting in auction markets. For example, knowing the price of recently auctioned items influences the reservation price of buyers and the minimum price of sellers in auctions for art and other rare goods.

Because surveys of competitors and other steps in the process of changing prices (such as changing and verifying tag changes) are costly to undertake, Levy, Bergen, Dutta and Venable (1997) find that the costs to a retail store of changing prices are quite large. Examining several large U.S. supermarket chains, they find that the fixed cost is about $\$ .52$ per price change; such costs are "fixed" in the sense that they do not depend on the size of the price change. (Because the cost of 
changing a menu also does not depend on the size of the price change, such costs are usually called "menu costs,”). Using a different methodology Slade (1996) finds the fixed costs of a retail price change to be even larger.

\subsection{Individual Firm and Worker Evidence}

One of the great accomplishments of research on wage and price rigidities in the 1980s and 1990s is the bolstering of these case studies and casual impressions by quantitative evidence from thousands of observations of price and wage setting collected at the firm, worker, or union level. By carefully studying these data one can learn much about the nature of wage and price rigidities in the Unites States and other countries. Some of the conclusions I draw from these data are summarized in section 2.3 below, but it is worthwhile to consider in detail several of the individual research studies.

\section{Direct Evidence on Wage Setting}

Most quantitative microeconomic information on wage setting comes from government data collected on the union sector. For example, Taylor (1983) and Cecchetti (1984) use data from major union contracts in the United States to get some quantitative measures for wage rigidities. Unfortunately, the large labor union sector represents only about 10 percent of U.S. 
employment. More than half of the wage agreements in the union sector last for more than one year, with the remaining being either one year or two year contracts. Slightly over 50 percent of the multiyear contracts in this sector are indexed.

The data reported by Taylor (1983) demonstrate how the wage setting is highly nonsynchronized. In any one quarter only about 15 percent of the workers are adjusting their contracts. In any one year only about 40 percent are adjusting their contracts. For example, aerospace, trucking, and automobile workers contracts are generally renegotiated in different quarters.

Cecchetti (1984) computed a time series of average duration of wages in the United States for the large union sector. He found that the average period between wage changes was slightly less than 2 years (7 quarters) in the 1950s and 1960s when inflation was low, but then fell to about one year (four quarters) in the 1970 s during the high inflation period. Hence, there is some evidence that the length of the period between wage changes is sensitive to the underlying inflation rate. However, even in the years of the great inflation wages were set at fixed nominal levels for one year on average. Cecchetti (1984) also found evidence that the amount of indexing increased as the inflation rate rose from the 1960 s to the 1970 s.

Of course, quantitative observations on wage setting at the microeconomic level is not confined to the United States. For 
example, Fregert and Jonung (1986) provide evidence from Sweden. Their data show that contract length decreased in Sweden as inflation and monetary uncertainty rose. However, average contract length never dropped below one year. They also found that wage setting showed little synchronization until the 1950s when centralized wage bargaining was introduced. Recall that Japan is another country where much union wage setting occurs at the same time each year.

Lebow, Stockton and Wascher (1995), McLaughlin (1994), and Card and Hyslop (1997) provide evidence about wage rigidity in the United States using individual wage data from the Panel Study of Income Dynamics. Because these studies, which reach similar conclusions, are not restricted to union workers, they are an important addition to the earlier studies on unions. However, because the wage is only sampled once per year, these studies do not provide information about whether the average duration of fixed wages is less than one year. Card and Hyslop (1997), who also examine data from the U.S. Current Population Survey form 1979 to 1993, report that between 6 and 15 percent of workers (among those who do not change jobs) have their nominal wages unchanged from one year to the next, suggesting a relatively small number of workers whose wages change less frequently than once per year. Card and Hyslop (1997) also report that the frequency of wage adjustment 
increases with inflation: during the high inflation period of the late 1970 s, only 6 to 10 percent of workers with the same job had unchanged wages from one year to the next, while during the lower inflation period of the 1980s the fraction of workers with unchanged wages was close to 15 percent. This confirms the results observed by Cecchetti (1984) using union wage data in the United States and Fregert and Jonung (1986) for Sweden. Card and Hsylop (1997) also report information on downward wage rigidity (again for annual wage changes) and find that a significant fraction of workers (15 to 20 percent) experience nominal wage reductions from one year to the next. This suggests that downward wage rigidities are no more significant for macroeconomics than upward wage rigidities. In fact, few of the models of price and wage rigidities used empirically in macroeconomic models make use of the distinction between upward and downward rigidity-in particular asymmetric rigidities have little relevance for the key empirical correlations mentioned in the introduction.

\section{Indirect Evidence on Wage Setting}

The microeconomic evidence on wage setting procedures can be supplemented with more indirect evidence based on macroeconomic data. If some structural assumptions about the general form of wage setting are made, it is possible to extract 
information about individual wage setting mechanisms from the autocorrelation functions of aggregate time series data. The indirect method is similar to estimating the parameters of utility functions or production functions from data on consumption and investment. The duration of fixed nominal wages-and the distribution of the different durations in the economy-has implications for the aggregate time series; from the time series data one can back out estimates of the wage duration distribution. Examples of these indirect methods are Benabou and Bismut (1987), Levin (1991), Taylor (1979b, 1993), Montgomery (1983), Christiano (1985), and Backus (1984) Benabou and Bismut (1987), Levin (1991), and Taylor (1993) examine the distribution of workers by length of wage setting interval in the United States. There are similarities in the results even though different data sets are used. Benabou and Bismet (1987) find that the average length of time between wage adjustments is about 1-1/2 years with a mode length of one year; the distribution of workers by contract length is not geometric: there are fewer workers with one quarter wage setting intervals than four quarter intervals.

Levin (1991) also reports estimates of a cross sectional distribution of wage changes in the United States. He finds that about 10 percent of wages are adjusted in one quarter, 25 percent in two quarters, and 65 percent in four quarters. Levin uses 
quarterly data on aggregate wages to obtain these estimates.

Using a less flexible geometric/exponential distribution assumption and focussing on Canada, Backus (1984) used exchange rate data to infer a median contract length slightly over a year, ranging from 5.4 quarters to 8.4 quarters.

Estimates reported in Taylor (1993) also indicate that annual contracts are the most common length of wage setting interval. Aggregate time series for wages in the United States imply that about 80 percent of workers have annual contracts; the fraction is somewhat smaller in Canada and Germany. Estimates of time-varying cross-section distributions are also reported in Taylor (1993) to accommodate some synchronization as in the case of the Shinto mechanism in Japan. (The distribution of wage changes can not be the same in each quarter in Japan because more workers have their wages adjusted in the Spring quarter). But, even in the Japanese economy, not all workers have wage adjustments in the second quarter. Some annual wage changes occur in the summer quarter and not all annual wage contracts are adjusted as part of the Shunto. Moreover, wages for some workers change more frequently than once per year. According to the estimates in Taylor (1993), aggregate wages behave as if 88 percent of wage contracts in Japan are annual, 12 percent are adjusted every quarter, and a negligible amount are adjusted every two quarters. Of the 88 percent, 42 percent of workers 
have their wages changed in the spring quarter, 26 percent in the summer quarter, 16 percent in the fall quarter and 3 percent in the winter quarter.

Some empirical researchers have also endeavored to determine whether wages are set relative to the prevailing wages as the casual observations mentioned above indicated. They use auxiliary structural assumptions about the wage process to derive spillover effects from aggregate data. Montgomery (1983) and Benabou and Bismet (1987) report little evidence of such spillovers, but these estimates require strong auxiliary assumptions.

In sum, these empirical studies suggest that the most common wage setting interval for the United States is about one year and that wage setting dates are staggered. However, a potential problem with these indirect estimates is their dependence on time aggregation of the quarterly data employed. Using continuous time econometric methodology, Christiano (1985) examined whether any wage setting intervals were shorter than the minimum quarterly interval in the aggregate wage data, and found evidence that there were some that short. These disadvantages of the use of the indirect methods point to the great value of better data on wage setting in the economy as a whole. 


\section{Direct Evidence on Price Setting}

Carlton (1986, 1989), using actual transactions price data that originated with Stigler and Kindahl (1970), has documented in great detail the extent of price rigidity for a wide variety of products in the United States. (Carlton (1989) also provides a useful summary of studies of price rigidity prior to Stigler and Kendall (1970). One of the most interesting early findings, attributed to F.C. Mills, is that the empirical frequency distribution of price change is U-shaped: goods with low frequency and high frequency price changes are more common than goods with medium frequency price changes). For most product groups, Carlton (1989) found that the time between adjustment of transactions prices seems remarkably long: ranging from about 1-1/2 years for steel, cement, and chemicals to about $1 / 2$ year for plywood and nonferrous metals. Carlton found little evidence for a fixed cost of adjusting prices, but observes a positive correlation between industry concentration and price rigidity.

Cecchetti (1986) collected data on U.S. magazine prices and also found price changes to be remarkably infrequent. In the 1950 s the average length of time between price changes was 7 years; in the high inflation years in the 1970s the time between price change was much lower at 3 years, but still remarkably infrequent given the changes in demand and costs during such 
long periods. Similarly, Kashyup (1995) found that mail order companies keep their catalog prices fixed for periods ranging from six months to two years.

Surveys of pricing policies at firms by Blinder (1994) and by Blinder et al. (1998) confirms the findings of Carlton and Cecchetti. Blinder (1994) found the mode frequency of price adjustment for firms in the survey to be one year. About 40 percent of firms tend to change their prices once per year, while only 10 percent change prices more frequently than once per year; the remaining 50 percent leave their prices unchanged for more than a year. Blinder (1994) also reports that the mean lagged response of price changes to changes in demand or costs is about three months and is invariant to whether the change is positive or negative, supporting Carlton's (1989) result. In another study of survey data, Buckle and Carlson (1995) found that the average duration of prices at small business was about 8 months in the United States during the 1980s and 1990s and about 7 month in New Zealand during the early 1990s. These durations are only slightly smaller than Blinder's findings. Buckle and Carlson also found that the average duration between price changes was shorter in periods of higher inflation.

Until very recently few of the studies of price setting have examined directly the degree to which prices are set in a staggered or synchronized fashion. Domberger and Feibig 
(1993) look at the amount of staggering by examining the skewness of the distribution of price changes. They look at prices in 80 disaggregated industry groups in the U.K. They find a significant lack of symmetry, indicating that many prices are not changed in a given quarter. Moreover, the sign of the skewness is related to the sign of the average price change. An increasing average price causes a rightward skew, and a decreasing average price causes a leftward skew.

Using a data set on retail store prices, Lach and Tsiddon $(1992,1996)$ find that the prices at retail stores are staggered across different price-setters. Eden (1994a), Levy et al. (1997), Warner and Barsky (1995) also examine the patterns of individual price changes at the retail level. The data used by Lach and Tsiddon consist of the prices of different meat products and wines at retail stores in Israel. They find that in any given month only a fraction of stores are changing the price of a given meat product or wine. The monthly fractions of stores changing prices are usually in the 30 percent to 40 percent range. Interestingly they find that price changes for different products within a store are highly synchronized. When stores change prices they seem to change the price for most of their products at the same time: within-store synchronization. But most stores make these adjustment at different times: across-store staggering. Dutta, Bergen and Levy (1997) provide evidence of much more 
frequent price change at the retail level than would be expected from the work of Carlton (1986), Cecchetti (1986), and Blinder (1994). Dutta, Bergen and Levy (1997) examine retail and wholesale prices of several types of frozen and refrigerated orange juice in the Midwestern United States. They find that orange juice prices at supermarkets change very frequently: about every 2 weeks, much more frequently than the price change observed by earlier researchers. Dutta, Bergen, and Levy (1997) argue that the frequent price adjustment in their study reflects the highly competitive nature of the supermarket business in the Midwest. Such rapid price adjustment may also reflect weekly, monthly, or seasonal discounting-the price could simply fluctuate between a rigid "regular" price and another "rigid" sale price, and not reflect any true price flexibility. In fact, Dutta, Bergen, and Levy (1997) find the adjustment of retail orange juice prices to changes in costs to be somewhat slower than the average duration of prices-about three to six weeks-in comparison to the twelve to sixteen weeks reported by Blinder (1994).

\subsection{Summary of Findings about Price and Wage Setting}

It is difficult to summarize briefly the large amount of microeconomic evidence on wage and price setting discussed above. And we still have much to learn from this evidence. But 
I would emphasize the following general features of price and wage setting in a market economy based on this research:

(1) While casual observation may suggest that wage rigidity is greater than price rigidity, the detailed studies do not provide evidence that one form of rigidity is more significant than the other: the studies suggest that price changes and wage changes have about the same average frequency-about one year. It would be inaccurate and misleading to build a model in which the average frequency of price or wage adjustment is longer than one year. Price and wage rigidities are temporary. But one should also feel comfortable with a model that assumes that prices and wages do not all change instantaneously and simultaneously, as if determined on a spot market with full information. And there is no empirical reason-aside from the need for a simplifying assumption or the desire to illustrate a key point - to build a model in which wages are perfectly flexible (determined on a spot market with full information) while prices are temporarily rigid, or visa versa.

Except for the findings of Blinder (1994) and Dutta et al (1997) on the effect of changes in costs on prices, this review of wage and price rigidities has said little about the connection between prices and wages, a subject taken up in the chapter by Rotemberg and Woodford (1998) in this Handbook. There is a long history of thought on the behavior of real wages, or product 
wages, over the business cycle, leaving the impression that there is little correlation, either positive or negative, between real wages and the business cycle. Domowitz, Hubbard, and Peterson (1986) and Carlton (1989) review the empirical literature on the relationship between price rigidities and wage rigidities. There is little agreement among empirical researchers about whether the mark-up of price over costs is procyclical or countercyclical. Of course there is a strong correlation between the growth of real wages and long term productivity growth, as the slowdown in productivity and real wage growth in the 1970s illustrates. But this is a correlation between long term trends, not a business cycle phenomenon related to the effects of money on the economy.

(2) There is a great deal of heterogeneity in wage and price setting. In fact, the data suggest that there is as much a difference between the average lengths of different types of price setting arrangements, or between the average lengths of different types of wage setting arrangements, as there is between wage setting and price setting. Grocery prices change much more frequently than magazine prices-frozen orange juice prices change every two weeks, while magazine prices change every three years! Wages in some industries change once per year on average, while others change once per quarter and others once every two years. One might hope that a model with 
homogeneous "representative" price or wage setting would be a good approximation to this more complex world, but most likely some degree of heterogeneity will be required to describe reality accurately. It is worth noting that the aggregate time series studies of Christiano, Eichenbaum, and Evans (1998) and Stock and Watson (1998) also show considerable heterogeneity in price and wage setting: for example, commodity prices seem to respond more quickly to money shocks than general price indices or than wages.

(3) Neither price setting nor wage setting is synchronized. Except for cases of national union bargaining, wage setting is staggered through time, whether one looks at union or non-union workers. Price setting is also staggered through time. These facts, which are apparent in casual observation, are confirmed in studies of wages, retail prices, and industrial prices.

(4) The frequency of wage and price changes depends on the average rate of inflation. Data from union workers and nonunion workers in different countries show that the frequency of wage setting increases with the average rate of inflation. Similarly, prices at small businesses, industrial prices, and even the prices of products like magazines are adjusted more quickly when the rate of inflation is higher. This dependency of price and wage setting on events in the economy is one of the more robust empirical findings in the studies reviewed here. However, 
it should be emphasized that for the range of inflation rates observed in the developed economies in the 1970s the average duration of wages and prices remained high. Moreover, we have no empirical evidence that anything other than a change in the inflation rate would change the frequency of price and wage adjustment, though one would expect legal or technological changes that increase the cost of changing prices would reduce price adjustment frequency. For a given average inflation rate, constant frequencies of price adjustment may not be a bad assumption to make in an empirical or policy model.

\section{Market-Clearing and Expected Market-Clearing}

\section{Approaches}

Having examined the nature of price and wage setting at the microeconomic level, I now turn to a discussion of how price and wage rigidities can explain the impact of money on the economy. I focus on explanations of the impact effect of money on real output in this section, considering both market clearing and expected market clearing approaches. In general I assume that expectations are endogenous and described by the assumption of rational expectations. The rational expectations assumption rules out the possibility that biased or adaptive expectations are a source of monetary non-neutralities, though I briefly discuss learning models which can temporarily result in such biases. 


\subsection{Market-Clearing Models}

Market clearing models assume that prices and wages can adjust instantaneously to satisfy equilibrium conditions. In order for such models to explain the slow adjustment of prices and thereby explain the impact of a change in money on the economy a la Hume and Friedman, it is necessary to posit some lack of information by people which slows down the adjustment of prices endogenously. Imperfect information about whether a change in the money supply or some other factor is the source of the shift in a firm's demand curve, for example, may cause prices to change by less than they would if the firms were fully informed. Thus, prices become temporarily rigid or sticky in an otherwise perfectly flexible price model.

Robert Lucas's (1972) path-breaking "expectations and the neutrality of money" paper-which introduced rational expectations and dynamic optimization into economy-wide monetary models-takes this approach. McCallum (1984) provides a good review of this model and Lucas (1996) provides a recent survey of the general imperfect information approach in comparison with other approaches. The Lucas (1972) model is an overlapping generations model with rational expectations in which trading takes place in decentralized markets. The overlapping generations model assumption is used to create an 
endogenous demand for money. The old, who are neither able to store goods they produce when young nor produce goods when old, use money to pay the young for the goods. When the old exchange money for goods a price is determined. Under certain uniqueness assumptions, a single equilibrium price level can be found in each period. If the money supply is constant, and distributed evenly to the old, then the price level will be a constant. When everyone is perfectly informed, the price level will be proportional to the money supply. Thus, with perfect information there are no price rigidities as defined here: a once and for all increase in the money supply will lead to a proportional increase in the price level and employment and production will be unchanged.

Price rigidities arise as a result of limits on information that prevent a realization of the money stock from being revealed to both the young and the old. The mechanism for limiting information is that trading takes place in two distinct markets. Then an increase in the price in one of the markets can signal either (1) that the money stock has increased, in which case there is a general increase in all prices and no need to change production, or (2) that there are fewer suppliers in the market and that the relative price has increased, in which case it makes sense to increase production. Hence, with limited information about the source of the price rise, suppliers must solve a signal 
extraction problem; the solution to the problem is to increase supply when the price rises, but by an amount that is less than the increase in the money supply. The response of prices to the increase in the money supply depends on the relative variability of money supply changes and market specific shocks. Thus, in this case there is a price rigidity: the price level rises by less than the increase in the money supply and production increases.

\section{Empirical Tests}

Lucas (1973) provided the first test of this model; he looked at the price-output behavior in several countries and found evidence that an increase in the variability of the general price level tended to raise the response of prices to changes in aggregate demand as predicted by the theory. Later, Ball, Mankiw, and Romer (1988) provided further support. For example, in a sample of 43 countries Ball, Mankiw and Romer (1988) find a significant negative relationship between the response coefficient of real output to aggregate nominal demand shocks (a more general measure of demand than the money supply) and the variability of nominal demand.

Soon after the Lucas model appeared, Barro (1977) endeavored to test the theory by empirically distinguishing between unanticipated and anticipated changes in money, finding that the effects of unanticipated money were larger, as predicted 
by the theory. Barro's study triggered an enormous amount of research and debate about whether anticipated money had any effect at all. Because his tests could not completely distinguish between limited information models and other models with rational expectations (such as the ones discussed later in this paper) that also predicted a difference between expected and unexpected money, questions were raised about the relationship between his test and the Lucas theory. See Mishkin (1988) for a good summary and econometric assessment of this debate.

Three types of empirical results, however, raised questions about market clearing models with imperfect information as an explanation of the impact of money on the economy. First, contrary to the theory, actual measures of misperceived changes in money had little impact on production; Barro and Hercowitz (1980), for example, provided evidence for this by comparing preliminary and revised data on the money supply in the United States; the difference between the preliminary and the revised data was taken as a measure of misperceived money. One can question the Barro-Hercowitz method as taking the Lucas model too literally--clearly many people are unaware of the money supply even after it is revised. Perhaps a better test of the spirit of the model would use a more general measure of aggregate demand as in Ball, Mankiw and Romer (1988). Nevertheless, the information limitations assumed in the 
Lucas model do seem strong without direct evidence for their existence.

A second empirical result that raised questions about the market clearing approach with limited information, is that unanticipated changes in prices seem to explain only a small fraction of the changes in production over the business cycle, again contrary to the causal mechanism of the model when taken literally. Sargent (1976), for example, showed that unanticipated changes in prices had little effect on production using data for the United States. However, like the Barro-Hercowitz tests, these tests may focus too much on the details of the Lucas model and not enough on its more general implications. For example, in models with sequential purchase restrictions (such as Lucas and Woodford (1994) and Eden (1994b)), an unanticipated increase in demand causes an increase in sales without an immediate increase in prices to signal more production.

A third empirical shortcoming relates to the persistent effects of a money shock on real output. In market-clearing limited information models, the duration of the effect of a money shock on real output is no longer than the time it takes to resolve the uncertainty about the source of the shock. It is unlikely that such information would take longer than a few months let alone longer than a year to obtain. Hence, without adding other sources of persistence the market clearing models with limited information have 
difficulty explaining a key fact about the money, real output, inflation relationship. To be sure, it is possible to add in such persistence effects through adjustment costs or inventories, but doing so leaves other aspects of the business cycle-such as the reverse dynamic cross correlations between inflation and output discussed in the introduction-unexplained. It is because of these difficulties in explaining persistence, in my view, that most estimated economywide monetary models do not utilize the perfectly flexible price, market clearing, assumption, even with limited information.

In any case, there has been relatively little research in recent years on imperfect information as a source of price rigidities in models with perfectly flexible prices. However, for reasons discussed below it is likely that a complete theory of price rigidities will eventually involve elements of the limited information theory, though perhaps in conjunction with the staggered wage and price setting formulations discussed below. One rationale for infrequent price changes stems from the information value that a stable price conveys to customers. Moreover, as discussed below, the microeconomic foundations of the staggered contracts models-and in particular why staggering even exists--involves imperfect information about whether a shock is temporary or permanent or local or economy-wide. 


\subsection{Expected Market-Clearing Models}

Soon after the Lucas (1972) model appeared, several researchers began to try to incorporate some form of sticky price or wage formation directly into rational expectations macro models, as an alternative to the imperfect information approach. This research originally had two objectives. The first objective was to develop new econometric models that could be used for monetary policy evaluation. That existing econometric models with adaptive expectations and arbitrary lag structures were inadequate for this purpose was shown clearly in the Lucas (1972) paper and even more transparently in Lucas's (1976) critique paper, which showed, using the example of the outputinflation tradeoff, the pitfalls of doing monetary policy evaluation without paying careful attention to expectations and the reactions of agents in the model. In order to overcome these pitfalls it was clear that a model with rational expectations was needed. If one had doubts about the ability of the imperfect information theory to explain fully the impact of monetary policy on the economy, then a sticky price formulation was a good alternative. Its long tradition in macroeconomics (among both monetarists and Keynesians) and the hope that it could help explain the persistence effects of monetary shocks as well as the impulse effects made it attractive.

The second objective was to respond to the work of 
Sargent and Wallace (1975) which showed that, under Lucas's (1972) imperfect information assumption with perfectly flexible prices, monetary policy had no effect--the so called "policy ineffectiveness proposition". Thus, the second objective of the research on sticky prices was to demonstrate that this proposition was due to the flexible price assumption rather than to the rational expectations assumption. Another approach to explaining the real effects of money in rational expectation models with perfectly flexible prices assumes that people must learn about monetary policy during a "transition" to rational expectations (Taylor (1975) and Brunner, Cukierman and Meltzer (1980)). Models with learning have developed considerably in the 1980s and 1990s as discussed in the chapter by Evans and Honkapohja (1998) in this Handbook.

Incorporating sticky prices or wages directly into an economy-wide rational expectations model meant assuming that prices or wages are set in advance of the market period when they apply and then are fixed at that level during the market period. For example, automobile firms might set their price $p_{t}$ for the quarter $t$ at the start of quarter $t-1$ and then keep the price at that value throughout the market period. Or firms might set the wage $w_{t}$ for year $t$ at the start of period $t-1$ and set the wage $w_{t+1}$ for the year $t+1$ at the start of period $t$, and so on. To make this model operational in an internally consistent rational 
expectations model of the economy, one might assume that prices or wages are set in such a way that markets are expected to clear during the period in which the price or wage applies. If we let $S_{t}\left(p_{v}\right)$ represent supply in period $t$ and $D_{t}\left(p_{t}\right)$ represent demand in period $t$, then expected market clearing simply means that the price $p_{t}$ which is set in period $t-j$ is chosen so that

$$
E_{t-j}\left(S_{t}\left(p_{\nu}\right)\right)=E_{t-j}\left(D_{t}\left(p_{\jmath}\right)\right)
$$

where $\mathrm{E}_{\mathrm{i}-\mathrm{j}}$ is the conditional expectation given information through perids $t-j$. This is the approach taken by Fischer (1977), Gray (1976) and Phelps and Taylor (1977) to incorporate price and wage rigidities into economy wide models. In applying this approach Phelps and Taylor (1977) focussed on the aggregate price level; they assumed that firms set prices one period in advance so that expected aggregate demand for goods (a negative function of the price level) equals expected aggregate supply. Fischer (1977) and Gray (1976) assumed that wages were set in advance in an analogous fashion with the price level perfectly flexible. They assumed that the wage was set so that the expected quantity of labor supplied equaled the expected quantity of labor demanded. In other words, in the Fischer and Gray models the wage is set in advance and $D$ and $S$ refer to the economy-wide labor market during the period when the wage 
applies, while in the Phelps and Taylor (1977) model prices are set in advance and $\mathrm{D}$ and $\mathrm{S}$ refer to the aggregate goods market during the period when the price applies. This is also the approach taken in more recent work by Cho (1993), Cho and Cooley (1995), and Rankin (1998) to incorporate price or wage rigidities into real business cycle models, though the D and $S$ functions in these models are far more complex than in the relatively simple macro models in which price and wage rigidities were inserted in the mid-1970s.

When setting prices or wages, agents in the model are assumed to make forecasts of supply and demand conditions in the future. Because the forecasts of supply and demand depend on the price in the next period, it is possible to find a price so that the expected quantity supplied equals the expected quantity demanded as shown in equation (3-1). This price is the expected equilibrium price level; it is this value which is assumed to be set in advance of the market period and then not changed. Actual supply and demand conditions will differ from these expected values because of unforeseen shocks. But because the price is fixed, the actual quantity demanded will not equal the actual quantity supplied-hence there is an excess demand or excess supply. The convention is then simply to assume that the quantity demanded determines the supply. For example, firms are assumed to supply whatever is demanded at the fixed price 
for that period. In the meantime the price is set for the next period and the model proceeds through time.

Of course, this expected-market-clearing mechanism describing how the price is determined is not necessarily a realistic description of how firms actually set prices, no more than the standard market clearing assumption in perfectly flexible price models is meant to be a realistic description of how firms actually set prices. In the equilibrium models, it is hoped that the market clearing approach gives good predictions and so it is with the "expected equilibrium" models.

One advantage of this approach to sticky prices or wages is that the long-run neutrality of monetary policy is always preserved, a point first emphasized by McCallum (1982) in an earlier survey. However, there is a serious disadvantage: the expected-market-clearing approach provides no explanation of the persistence of monetary shocks. The persistence caused by this type of sticky wage or price mechanism could last no longer than the longest lead time for wage and price setting. Recall that the review of the studies of wage and price setting in the previous section showed that the average duration of nominal wages and prices was no longer than one year. Yet the persistence of money shocks lasts well beyond one year. In other words, the expected market clearing approach has the same empirical shortcoming as the market clearing approach, and trying to remedy these 
shortcomings by introducing other sources of persistence leads to a counterfactual implication for the inflation and output dynamics.

It was in trying to apply the expected market clearly approach in constructing an estimated econometric model that I realized how serious this disadvantage was. The empirical problem with such a formulation was that real output jumped back to the full employment level much too quickly and sharply after a money shock. I found that in building an empirical model I could not use the expected market-clearing formulations that had proved useful in building the simple theoretical models of Phelps and Taylor (1977), Gray (1976), or Fischer (1977). In is interesting that Yun (1994, Chapter 2) had a similar experience when endeavoring to introduce sticky prices into an empirical real business cycle model; he found that setting a price for a single market period in advance could lead to no longer persistence than the length of the longest lead time in price setting, and for this reason he eventually adapted to an alternative approach used prior to the development of real business cycles-a version of the staggered price setting approach described in the next section.

In retrospect, it is interesting to observe that the persistence problems of the expected market clearing models with prices or wages set in advance are similar to those of the market clearing model with perfectly flexible prices and limited 
information. The persistence of a shock to money would not last beyond the length of the longest lead time for price setting or beyond the longest time for learning the source of an observed shock to aggregate demand.

\section{Staggered Contracts Models}

The staggered price and wage setting approach focuses on the nature of the price or wage decision itself, asking what would be a reasonable way to describe how prices and wages are set in different circumstances. Many of the general observations about real world price and wage setting described in Section 2 guide the formulation. These general observations include: (1) Wage and price setting appears to be staggered or unsynchronized; not everyone sets prices or wages in the same period. (2) Wages and prices are set at fixed values for fairly long periods of time (frequently called a "contract" period) and are frequently, though not always, non-contingent on events that occur during the contract period. Wage changes occur annually for many workers but the length of time varies and is not a fixed time length in many instances. Because price or wage setting is staggered these contract periods overlap with each other-hence, the term "staggered contracts" (3) When setting prices or wages, firms find that other prices and wages in the economy, or at least in closely related markets, are relevant for their decisions; this is 
true both for competitive markets and for markets where price setters have a degree of market power.

\subsection{A Simple Price Setting Model}

The staggered contract model developed in Taylor (1979a, 1980a) was explicitly designed to have these features; it is a simple model of price or wage setting designed to highlight certain key properties of real world price and wage setting. The equations are essentially the same for wage setting and price setting. Consider the case of price setting. In the basic model prices are set for a fixed number $(\mathrm{N}>1)$ of periods and are not changed during the length of this $\mathrm{N}$-period "contract period" Each period, $1 / \mathrm{N}$ of the firms change their "contract prices." At any moment of time, the prevailing price would be an average of the $\mathrm{N}$ outstanding contract prices determined in the current and the last N-1 periods. When setting the current price, firms would take account of both future and past price decisions of other firms because these would be part of the prevailing price. Thus the equations have both forward looking and backward looking terms which are implied automatically from elementary considerations about how prices are set. These staggered contract equations had the feature that there is no long run trade off between inflation and unemployment: regardless of the steady state inflation rate the unemployment rate would equal the natural rate, 
although this property requires that future prices are not discounted when setting today's price, a property that may be a good approximation for short contracts of one year or less.

To be concrete, suppose that $N=2$, and that $p_{t}$ is the $\log$ of the average price prevailing in period $t, x_{t}$ is the log of the price set in period $t$ to apply to period $t$ and $t+1$, and $y_{t}$ is the $\log$ of aggregate real output. Then, the basic staggered price setting model is:

$$
\begin{aligned}
& p_{t}=.5\left(x_{t}+x_{t-1}\right) \\
& x_{t}=.5\left(p_{t}+E_{t} p_{t+1}\right)+\gamma y_{t}+\gamma E_{t} y_{t+1}+\varepsilon_{t}
\end{aligned}
$$

where $\varepsilon_{t}$ is a shock to price setting. The first equation states that the current price is the average of the two outstanding " contract prices”. Equation (4-2) posits that this contract price will depend on prices prevailing during the contract period and on a measure of total demand in the economy during the two-period contract length. In Taylor (1979a, 1980a) I viewed the role of $y_{t}$ in this equation as representative of excess demand in the markets during the periods when $x_{t}$ applied, but as discussed below this is only one interpretation. The model can be closed by assuming a simple demand for money function such as $\left(m_{t}-p_{v}\right)=y_{t}$ where $m_{t}$ is the $\log$ of the money supply and by specifying a stochastic 
process for the money supply.

Suppose for example that $m_{t}=m_{t-1}+\eta_{t}$ where $\eta_{t}$ and $\varepsilon_{t}$ are serially uncorrelated random variables. Then, by substituting for $y_{t}$ in equation (4-2) using the demand for money and then substituting for $p_{t}$ using equation (4-1) one can easily derive an autoregressive moving average process for $\mathrm{y}_{\mathrm{t}}$ in which the autoregressive parameter (the coefficient on $\left.y_{t-1}\right)$ is $a=c-\left(c^{2}-\right.$ $1)^{-1}$ where $c=(1+\gamma)(1-\gamma)^{-1}$ and the moving average terms depend on the shocks to money and the price setting equation. The autoregressive parameter a is inversely related to the parameter $\gamma$. For small $\gamma$, the parameter a will be large and there will be a lot of persistence. Hence, $\gamma$ is a key parameter.

The autoregressive part of the process for $y_{t}$ arises because he price $x_{t}$ set by one firm partly depends on the price $x_{t-1}$ set at other firms-as can be seen by substituting equation (4-1) into (42). Because of the autoregression, a shock to the money supply has a long drawn out effect on output and the price level. The autoregressive term is analogous to a dynamic multiplier and for this reason I used the term "contract multiplier" to describe this persistence effect. This autoregressive component is why the effect on output lasts much longer than the length of the longest contract ( 2 periods here).

West (1988) and Phaneuf (1990) showed with more detailed models and data from the United States and other 
countries, that the persistence could be large enough to explain the near unit root behavior that had been associated with real business cycle models. In other words they showed that near unit root behavior was consistent with a monetary theory of the business cycle with relatively short lived staggered prices and wages. Moreover, as I showed in Taylor (1980b), there is also a pattern of reverse dynamic cross correlations implied by this model in which a higher level of real output is followed by a higher price level, while a higher price level is followed by a lower level of real output-in other words real output Grangercauses the price level (positively) while the price level Grangercauses real output (negatively). This reverse correlation is found in the data from many countries as reported in Taylor (1980b) and mentioned in the introduction to this chapter. Hence, even this highly stylized model is capable of explaining key facts of the dynamic relation between money, output, and the price level. Note, however, that these facts pertain to the behavior of the price level rather than the rate of inflation, an important issue to which I will return in the discussion of inflation persistence below.

\subsection{More General Staggered Wage and Price Setting Models}

Given the heterogeneity of wage and price setting structures summarized in Section 2 , it is likely that the simple 
uniform-length staggered contract structure in equation (4-1) would have to be generalized for empirical work to describe a world with a multiplicity of contracts of different lengths. For example, rather than have all prices or wages change every $\mathrm{N}$ periods, one could have a range of contracts of lengths $N_{1}, N_{2}$, $\mathrm{N}_{3}$, ...representing different types of prices or wage setting arrangements. Thus some prices would be set for a relatively long period of time while others would usually change more frequently. One way to represent such a model is to generalize equation (4-1) as

$$
p_{t}=\sum_{s=0} \pi_{s} x_{t-s}
$$

which is drawn from Taylor (1979b); equation (4-2) can also be generalized in an analogous fashion with $\pi$-weights replacing $1 / \mathrm{N}$ or $1 / 2$ in the case of $N=2$. In the special case where $\pi_{0}=\pi_{1}=$ .5 and the rest of the $\pi$ 's are zero, equation (4-3) reduces to equation (4-1), the two period price setting case. Alternatively, if there were an equal number of prices with durations of one through four quarters, then the $\pi$ weights would decline linearly. In the next several sections, I consider versions of equation (4-3) that have proved useful in research. 


\section{Fixed Duration Models}

In a series of empirical studies (Taylor (1979b, 1983, 1993)) I used the general formulation in equation (4-3) in several different ways, none of which restricted the parameters to any special stylized case such as equation (4-1). This allowed for a general frequency distribution of different contract lengths: some workers and firms would set their price or wage each quarter, others every two quarters, others every year and so on.

In Taylor (1979b) I estimated the $\pi$ weights using aggregate wage data for the United States. I assumed a flexible functional form for the pattern of the $\pi$ weights in order to reduce the number of parameters - the functional form allowed the frequency of contract length to increase, reach a peak, and then decrease. By estimating the parameters of that distribution, I was able to infer the distribution of contract lengths in the United States. In Taylor (1983) I calibrated the $\pi$ weights using union wage data in the United States; the observed contract distribution varied in length from 4 quarters to 12 quarters. The resulting model was then used to simulate different disinflation paths for the United States to follow to bring the inflation rate down from the high levels of the late 1970s and early 1980s. Finally, in an estimated multicountry model (Taylor (1993a)) I estimated implied distributions of contract length for the largest seven industrialized countries, with the allowance of more 
synchronization in Japan, where observation of the wage setting process suggested there would be synchronization. (These estimates were discussed in the section on indirect observations of wage setting above).

Blanchard $(1983,1987)$ significantly extended the idea of unsynchronized price and wage setting to a complete stage-ofprocess model in which the price of inputs affects the price of outputs which then affects the price of an input to another firm and so on. The process of passing through price changes at each stage of production generates staggered price setting with the dynamics depending on the input-output structure of the economy. Hence, this provides another way to calibrate, or at least interpret, staggered price and wage setting models. Gordon (1981) also places great emphasis on stage-of-process effects in models of aggregate price dynamics.

Christiano's (1985) extension of the staggered price and wage setting model also proved useful. He allowed for adjustment of contracts more frequent than the time interval for data collection and estimation. For example, Christiano's generalization could be used to estimate a model in which some contracts last only one quarter, but the data are annual. Using this approach Christaino was able to improve the goodness of fit of the simple staggered contract model.

Buiter and Jewitt (1981) generalized the staggered contract 
model to allow wage setters to take the real wages of other workers into account rather than nominal wages. They showed that this change preserved many of the dynamic properties of the basic model, but allowed for additional effects because different price indices might be relevant for workers and firms. This is especially relevant in international economics where distinguishing between consumer and producer prices allows one to consider the important implications of exchange rate passthrough.

\section{Random Duration Models}

Calvo (1982, 1983) developed a simple, but useful, version of equation (4-3) by assuming that the $\pi$ weights had a simple geometric form: $\pi_{\mathrm{s}}=\alpha$ for $\alpha<1$. Calvo's original suggestion was to convert the staggered contract model to continuous time and thus assume an exponential distribution. Moreover, Calvo (1982) provided a stochastic interpretation of the staggered contracts model: in his words "we basically adopt the same assumptions [as the standard staggered contracts model] except, to simplify the mathematics, we suppose that contract length is stochastic and independent and identically distributed across contracts." rather than described by a fixed distribution of contracts of different lengths. Calvo (1982) suggested that the equations could be interpreted as implying that the contracts 
ended randomly according to a geometric (or exponential) distribution, thereby leading to a random duration version of staggered wage setting. To complete the geometric version of the staggered price setting model, Calvo generalized equation (4-2) as in Taylor (1979b).

Levin $(1989,1991)$ proposed a more general version of the random duration model in which the frequency distribution of contracts is not necessarily exponential. He estimated the distribution for the United States and found it to be significantly different than geometric with one year wage setting intervals more common than shorter intervals. The stochastic interpretation implies that firms or workers will randomly change prices, which might seem less realistic than the assumption that the price changes occur at a typical time each year, such as in the spring. Backus (1984) and Chada (1987) found the geometric assumption useful in discrete time empirical formulations, but Levin (1991) and Benabou and Bismut (1987) found that the distribution of contracts is not generally geometric. Hence, the simple geometric assumption should probably be used with caution in empirical work.

\section{State-Dependent Duration Models}

The exogeneity of the price and wage change intervals in both the fixed and random duration staggered price setting 
models has been one of their most criticized assumptions. Making the price change or contract termination decision endogenous is important for policy or empirical work, especially if exogeneity is a poor approximation. Fortunately, a number of recent studies have begun to develop models in which the duration of price and wage decisions depends on the state of the economy; this approach is called state dependent pricing. In contrast the simple staggered price and wage setting model is called time-dependent pricing because prices change at fixed or randomly selected times.

Caplin and Spulber (1987) developed a widely-discussed model in which all prices are completely state dependent; that is, there is no explicit dependence on time as in the staggered contract models. With state-dependent pricing each firm is faced with fixed costs of price adjustment and uses an $(S, s)$ policy to determine whether the price will change and by how much (see Sheshinski and Weiss (1988) for more on (S,s) policies in price adjustment). Because not every firm will change its price in every period the resulting pattern of price adjustment looks just like staggered time-dependent pricing. However, Caplin and Spulber (1987) find the switch from pure time-dependent pricing to pure state-dependent pricing greatly reduces the effects of staggered wage and price setting on the macroeconomy. In particular they find that money can be completely neutral in such a model. The 
reason is that if all price setters are following a $(\mathbf{S}, \mathbf{s})$ policy, with a wide enough band, then they can all change prices by the full amount of a monetary shock as soon as the shock appears. In contrast with the time dependent pricing in the staggered price setting model discussed above, some firms will not change their price so that the aggregate price level adjusts slowly.

Tsiddon $(1991,1993)$ shows that slow aggregate price adjustment and the nonneutrality of money reappear if the changes in the money supply are highly persistent or have large swings. In such cases the size of the firm's price change is reduced leading to smaller changes in the aggregate price than the money supply. Conlon and Liu (1997) show that if firms change prices in response to other things than price misalignment (a product upgrade, a new model or a new product mix), then the nonneutrality of money reappears. Essentially this change results in a mixture of time dependent and state dependent pricing, a situation which probably better reflects reality than either extreme.

An important recent application of state dependent pricing is found in a general equilibrium model developed by of Dotsey, King, and Wolman (1996), who modified the geometric staggered contract framework of Calvo (1982) to allow for state dependent pricing. In the Dotsey, King and Wolman (1996) model the fraction of firms that are changing their prices in any 
one period increases when the inflation rate rises. This prediction of the model is supported by many of the papers surveyed in Section 2. An important advantage of the Dotsey, King and Wolman (1996) paper is that they embed statedependent pricing into an economy wide model and preserve some degree of time dependence. They find that the money, output, and price dynamics resulting from their state dependent model are not too dissimilar from the dynamics of the purely time dependent model discussed above.

Another example of state dependent pricing is the model of Caballero and Engle (1993). Like the Caplin and Spulber (1987) model, only a fraction of prices will be adjusted each period in the Caballero and Engle model. Thus staggered price setting emerges. However, Caballero and Engle (1993) assume that the probability that an individual price will adjust depends on both the size and the sign of the deviation of the price from some desired price. Caballero and Engle (1993) look at the implications of their model for time series behavior of the aggregate price level focussing on the producer price index. The detrended $\log$ of the index itself is described by a second order vector autoregression with coefficients of 1.68 and -.76 . The Caballero and Engle (1993) model with its emphasis on first order adjustment has difficulty mimicking this humped shape behavior implicit in a second order process, but at least the model 
generates the persistence or stickiness of the aggregate price levels found in the pure time-dependent staggered contract model.

\section{Bolstering the Theoretical Foundations of Staggered Contracts Models}

As described above in Section 4.1, the basic staggered contract model was constructed to be consistent both with certain observed features of price and wage setting behavior and with basic microeconomic principles about the operation of competitive or imperfectly competitive markets. In particular, the idea that the price and wage decisions of firms depend on the prevailing prices and wages-and thus on the price and wage decisions at other firms-is an essential characteristic of staggered wage and price setting equations. In a sense these equations endeavor to describe a price discovery process in markets with posted prices, much like the equilibrium of supply and demand equations is a description of price discovery in spot markets. Davis and Holt (1997) have noted the development of price rigidities in experimental markets with posted prices and it is likely that experimental economics will help improve on current formulations of staggered wage and price setting. Nevertheless, the price and wage setting mechanism in the original staggered contract models was not derived from an explicit maximization problem, and this lack of a formal optimization underpinning is a 
potential disadvantage that many researchers have pointed out. Fortunately, many studies over the years have provided a more solid microfoundation for these equations.

\subsection{Deriving the Optimal Price: The Role of Market Power}

Most formal derivations of price determination take as given either (1) the cost of adjusting price, or (2) the fixed (or possibly random) interval for setting the price. Subject to this constraint an optimal value of the price to maximize profits can be found. Arrow (1959) first pointed out the need for some degree of market power to make the price decision of a firm meaningful. He outlined a possible framework in which even competitive firms had a temporary degree of market power at the time of the price decisions. Prescott (1975) also outlined a model of price setting in which firms had some degree of market power, but the market is essentially competitive in that the efficiency conditions of competition hold.

Models in which firms have market power-due usually to a monopolistic competition assumption-so that an optimal price can be calculated are used frequently in studies of price and wage rigidity. In an early paper on this subject, Rotemberg (1982) assumed that firms face an explicit cost of adjusting prices, a cost that depends on the size of the price change. He also assumed that each firm faces a downward sloping demand curve. These 
assumptions enabled him to derive a price setting rule in which the actual price level adjusts slowly toward the optimal monopoly price. Rotemberg (1982) originally used this approach as an alternative to staggered price setting, but Rotemberg (1987) and Roberts (1995) show that the cost of price level adjustment model leads to very similar equations as staggered contract models.

In two influential papers, Svensson (1986) and Blanchard and Kiyotaki (1987) developed complete macroeconomic models in which monopolistic competition plays a role in determining the optimal price for firms. These models incorporate money formally and can be used to show the impact of a change in aggregate demand rising from changes in the money supply. In their original form, the Svensson (1986) and Blanchard and Kiyotaki (1987) models were static and were not addressed to the problems of persistence or dynamic cross correlations that are the main subject of this review.

\subsection{Towards Dynamic Optimizing Models of Staggered Price} and Wage Setting

Blanchard and Fischer (1989) developed a dynamic model that could address such issues. The model combines monopolistic competition with staggered price setting. The combination is achieved in two steps. The first step is to find the optimal price from a monopolistically competitive model without 
staggered price setting, such as Svensson (1986) or Blanchard and Kiyotaki (1987). For example, a typical optimal pricing rule would say that the price should depend on the average of other monopolistically competitive firms prices ( $p$ ) and on a constant times aggregate output (y), which would represent a demand shift. A linear version of such a rule would look like

$$
\mathrm{x}=\mathrm{p}+\gamma \mathrm{y}
$$

where $\mathrm{x}$ is the firm's price, $\mathrm{p}$ is the average of other firms prices, and $y$ is aggregate output.

Now, suppose that pricing is staggered with 2 period contracts so that the price $x_{t}$ must last for two periods: $t$ and $t+1$. Then it seems reasonable that firms would set their price to be the average of the optimal price during the two periods during which the price applies. This reasoning leads to the second step which sets

$$
x_{t}=.5\left(p_{t}+\gamma y\right)+.5\left(E_{t-1} p_{t+1}+\gamma E_{t-1} y_{t+1}\right)
$$

Note that equation (5-2) is identical in functional form (ignoring the random shock) to equation (4-2). Hence, pricing under monopolistic competition gives a more formal underpinning of the staggered price setting model. However, now the role of $y$ is 
to shift firms' demand functions rather than to serve as a measure of (excess) demand pressure in the market. Blanchard and Fischer then went on to describe various persistence properties when equation (5-2) is imbedded in a model. Because equation (5-2) is identical to equation (4-2), the properties are identical to those I discussed above. Romer (1996) presents a very useful textbook treatment of this type of derivation of the staggered price setting equation, providing useful details of the derivations and further discussion. Rotemberg's (1987) derivation of a staggered price setting mentioned above is similar to the one of Blanchard and Fischer (1989) described here, except that rather than using the example in equation (4-2) he uses the version of equation (4-2) with geometric declining weights on future p's and $y$ 's as in Calvo's (1982) geometric version of the staggered contract model (see the discussion following equation (4-3)).

Although the above derivation of the staggered price setting equations provides a helpful microeconomic interpretation, it is still not a fully optimizing treatment. In work that began in the mid 1980s, Akerlof and Yellen (1991) developed a dynamic model in which equation (4-2) or (5-2) emerged directly from a monopolistic competition model without the two steps described above. They showed how the simple staggered contract equations could be derived from a maximization problem in which monopolistically competitive 
firms interact.

Consider a simple two-firm model in which each firm faces a downward sloping demand curve and thus has a degree of market power. The demand curve depends on real income in the economy, its own price, and the price charged by its rival. (The

process determining real income is left unspecified, but is eventually related to the money supply as in other models). One firm sets prices in even periods and the other firm sets prices in odd periods. The prices are fixed at the same nominal value for two periods. The rival firm can be thought of as a monopolistic competitor that sets a constant nominal price every other period. Akerlof and Yellen (1991) show that if each firm chooses a price to maximize expected profits taking as given (1) the price set by the rival firm (a Bertrand price setter) and (2) income in the economy, then the optimal price is given by the simple staggered price setting model in equations (4-1) and (4-2). To get linearity in the decision rule, Akerlof and Yellen (1991) approximate the profit function by a quadratic.

\subsection{Staggered Price and Wage Setting in General}

\section{Equilibrium Models}

Although Akerlof and Yellen (1991) derived staggered price and wage setting equations from first principles, they did not endeavor to embed the equations in a fully optimizing model 
of the economy-that is, a model that includes utility functions for representative households. During the late 1980s and 1990s there has been a great amount of research aimed at doing just that. Nelson (1997) provides an excellent review of the most recent part of this research, but some discussion of earlier work is useful too. In one of the earliest studies along these lines, Deborah Lucas $(1985,1986)$ developed a full optimizing model in which some prices are determined in spot markets and some are determined in contract markets. The prices in spot markets are determined in the usual market clearing way. The wage contracts are assumed to last two periods; 50 percent of the contracts are set in odd periods and the other 50 percent are set in even periods. The contract specifies a fixed nominal wage for two periods: the current period and the next period.

Interestingly, Lucas $(1985,1986)$ developed a wage setting mechanism for the contracts in competitive markets, so that the results do not depend on the market power of firms. The terms of the contract are determined in a market clearing fashion. As stated by Lucas (1986), "In the process of competing for the $\mathrm{N}$ workers available to a given sector, the economy equilibrates so that the marginal utility gained from the wages paid over the contract period equals the marginal disutility of labor over the contract period." Note that this approach to modeling wage determination in the contracts is analogous to that used in the 
optimal contract literature (see Azariadis (1975)); it is different from both the monopolistic competition assumption and the expected market clearing approached mentioned above. Deborah Lucas $(1985,1986)$ used a cash in advance approach to money demand and has prices set for two periods, with decisions being made every other period. Simulations demonstrated the effect of the nominal rigidities on the effect of monetary policy. In her model, the amplitude of cycles was proportional to the fraction of markets with wage contracts compared with spot pricing.

Levin (1989, Chapter 2 and 1990) also developed an optimizing model in which wages are set in a staggered manner and determined optimally. Levin also obtained estimation and policy results. He estimated the model using maximum likelihood methods and U.S. data. He then stochastically simulated the model to derive optimal feedback rules for monetary policy, and calculated the tradeoff between output stability and price stability. Because the parameters of Levin's model were estimated he could obtain quantitative estimates of the policy rule and the policy tradeoff.

Yun $(1994,1996)$ developed a general equilibrium model with staggered price setting, both with a fixed and random duration. Because Yun uses monopolistic competition, his analysis of staggered price setting has similarities to that of Blanchard and Fischer (1989) above, but it is not a two step 
approach. Staggered pricing equations of the form of (5-2)

emerge from the optimization problem without requiring that one first find the optimal price without staggering and then inserting that price into the basic staggered price setting equations. A difference in the resulting equations is that prices in future periods are discounted relative to current prices; that is $\left(p_{t}+\gamma y_{t}\right)$ would get a larger weight than $\left(\mathrm{E}_{\mathrm{i}-1} \mathrm{p}_{\mathrm{t}+1}+\gamma \mathrm{E}_{\mathrm{t}-1} \mathrm{y}_{\mathrm{t}+1}\right)$ in equation (5-2) because the firms' profits in the second period would be discounted. Yun's approach shows explicitly how the single price in a staggered price setting model must balance out profits in different periods because the price cannot be at different levels in different periods.

Kimball (1995) discusses several results that emerge when he places formally derived staggered price setting equations in a general equilbrium model. Kimball (1995) noted that the parameters of the resulting equations may give less persistence than earlier estimated staggered price setting models (for reasons similar to those mention in my discussion of Blanchard and Fischer) and discussed several factors that could lengthen persistence that have proved useful in later work. In commenting on Kimball (1995), Woodford (1995) gives a nice comparison of the Yun $(1994,1996)$ and Kimball (1995) models.

Compared to other research in this area, the work by King and Wolman (1996) focusses more explicitly on policy analysis. 
King and Wolman (1996) develop a utility maximization model with price and wage rigidities. Like Deborah Lucas (1985,1986), Levin (1989), and Yun (1994) they add price rigidities to the model, using a staggered price setting model. Money enters their model through a transactions technology device in which monetary services allow for higher levels of consumption. As with Levin (1989) and Deborah Lucas (1985, 1986), money has a real effect in the model because of the nominal rigidities. King and Wolman (1996) examine inflation targeting procedures and other important issues in the design of monetary policy rules.

By the mid 1990s there were also a number of papers that added other forms of price and/or wage rigidities to a general equilibrium model. Hairault and Portier (1993), Kim (1995), and Ireland (1997) used a quadratic cost of price adjustment approach as suggested by Rotemberg (1982), while Cho and Cooley (1995) assumed that prices were set in advance in such a way that the overlapping features of staggered price setting would not play a role in producing persistence. Other work in this general area has been motivated by various policy, empirical, and methodological issues and includes Leeper and Sims (1994), Bernanke, Gertler, and Gilchrist (1998), Ohanian and Stockman (1994), Chari, Kehoe, McGrattan (1998) and others. The paper by Chari, Kehoe and McGrattan (1998) raised some puzzles 
about the ability of staggered price and wage equations to deliver persistent dynamics and is taken up along with several responses later in this chapter.

\subsection{Explanations of Why Price and Wage Setting is Staggered}

Although based on empirical observations, the staggering of wage and price setting is simply assumed in all the models discussed thus far in this paper from Taylor (1979b) through Chari, Kehoe, and McGrattan (1998). Why is price and wage setting staggered? This question has been pursued by many researchers in the 1980s and 1990s and is still the subject of debate. The question goes to the heart of the price discovery process in a market economy and well beyond macroeconomics.

Fethke and Policano $(1984,1986)$ develop a model in which wages must be set several periods in advance and then are fixed without contingencies. The question is whether in such a world the wage setting should be staggered or all occur at one time. Fethke and Policano (1984) proved that staggering is a good way for the economy to adjust to sector specific shocks. When disturbances are primarily due to relative, as distinct from aggregate, shocks, staggering of decisions is optimal because adjustments of some prices enable the sectors that are locked into fixed wages or prices to partially adjust. Parkin (1986) also shows that the degree of staggering depends on the relative size 
of aggregate shocks versus sector specific shocks. The analysis of monetary policy in this type of model is considered in Fethke and Policano (1987). They derive a Nash equilibrium where timing of monetary policy intervention and synchronization of contracts are simultaneously decided upon.

An entirely different explanation for the existence of staggering comes from informational considerations. Ball and Cecchetti (1988) show that staggering allows firms to obtain information about what is going on in other markets. By observing the price in other markets firms are able to extract information about whether shocks are aggregate or relative. In addition, Ball and Romer (1989) find that there is a more rapid adjustment to sector (idiosyncratic) shocks with staggering. As shown by Ball (1987), these microeconomic advantages are offset, at least in part, by macroeconomic disadvantages of slow aggregate price adjustment, a concept he refers to as "externalities from contract length." Sheshinski and Weiss (1988) consider the question of staggering in oligopolies where timing is endogenous. Lau $(1996,1997)$ explores the strategic issues between price setters in an oligopoly game. The strategic rationale for staggering was explored by Matsukawa (1986) in the case of wage setting.

In a recent paper, Bhaskar (1998) derives endogenous price staggering in a model with heterogeneous firms. Firms 
within an industry have stronger strategic complementarities than firms in different industries. This results in an equilbrium in which there is synchronization within industries but not across the economy. De Fraja (1993) also utilizes such strategic considerations in a model in which staggered price setting can be endogenous.

\subsection{Indexing and Optimal Contract Length}

A major puzzle in the area of wage and price rigidities is why contracts are fixed in nominal terms for so long. Gray (1978) provided at least part of the answer in a paper on the optimal degree of indexing. In a model in which there are both nominal and real shocks, Gray (1978) showed that it is not optimal to fully index a wage contract to a single variable like the price level. A still unsettled issue is why contracts would not be indexed to all relevant information. Complexity, asymmetric information, and measurement problems must all be part of the answer.

\section{Persistence Puzzles and Possible Resolutions}

A general theme of this paper is that the assumption of rational expectations and the need for economy-wide modeling, has led to more specific models of wage and price rigidity than before the rational expectations revolution. This greater 
specificity has led to the formulation of many statistical tests of the price and wage rigidity models. Several years ago, Blinder (1994) noted that models of price and wage rigidity have not been tested, saying, "Try to think of even a single case in which a theory of sticky prices has been rejected econometrically." But, while this criticism may apply to pre-rational expectations theories, it certainly does not apply to the price and wage rigidity models that have arisen since the 1970s. Indeed, the simple representative staggered contract model described in equation (41 ) is an example of a theory of sticky prices that-at least in that stylized form-was rejected econometrically as early as 1982 . In a 1985 survey paper I stated that "Empirical tests of the stickyprice models have not yet been as extensive as the informationbased models." (see Taylor (1985)), but they had already begun. Because of the extensive testing of staggered price setting and other the sticky price models in recent years, it would not be accurate to make that 1985 statement today. Recall first that staggered price and wage setting models do explain in broad terms the observations summarized in the introduction of this paper. For example, many of the serial correlation properties of the aggregate data--including the reverse dynamic cross correlation, the persistent effect of monetary shocks on real output, and the permanent effect of monetary shocks on prices-are all explained by the simple staggered contracts model. 
More generally, simulations of the impact of monetary policy shocks, summarized in Taylor (1993a), look much like vector autoregressions reported by Christiano, Eichenbaum and Evans (1998). However, when one looks more closely at the properties of the serial correlation, one starts to see discrepancies, which raise interesting puzzles. Most of these discrepancies are related to the ability of the models to explain persistent movements of real output or inflation.

In an early paper on testing the staggered price and wage setting model, Ashenfelter and Card (1982) found that the simple staggered contract model was inconsistent with the serial correlation of wages. Levin (1991) has shown, however, that the more general formulations of these models such as equation 4-3 above do pass goodness of fit tests like those proposed by Ashenfelter and Card (1982).

Another empirical criticism of the staggered contract model is found in Dezhbakhsh et al, (1984). They argued that the statistical Phillips curve correlations reported in Taylor (1980) arose after supply shocks, not demand shocks, and that correlations were actually based on forward looking derivatives (differences). While the point about the supply shocks is correct, the more typical statistical Phillips curve correlations would arise if demand shocks were correlated. A related point was made by Phaneuf (1987a, 1987b). He pointed out that uncorrelated 
demand shocks showed a negative effect after the length of the longest contract. This property can be avoided with serially correlated demand shocks.

\subsection{Inflation Persistence}

A widely discussed econometric problem with the staggered contract model is its apparent inability, without serial correlation or other sources of dynamics, to generate the persistence (or inertia) of inflation observed in the data. For example, Ball (1994) showed how it was possible to reduce inflation without recession--indeed with the right policy to have a boom! Phelps (1978), Taylor (1983), and Abraham (1987) also examined costless disinflations with rational expectations, but they did not relate this finding to empirical defects with the model. Though the inconsistency between these results and the observed costly disinflations can be easily explained by learning or by lack of credibility, the inconsistency raises some doubts about the ability of staggered contracts models with rational expectation to generate inflation persistence. The apparent inconsistency has led some empirical researchers to use a modification, proposed by Fuhrer and Moore (1995a, 1995b), of the staggered contracts model

Fuhrer and Moore (1995a, 1995b) present autocorrelation plots that nicely document some of the difficulties with the ability 
of the staggered contract model to produce inflation persistence. They show that the cross autocorrelation functions based on actual inflation and output data were not closely matched with the simulations of the basic staggered contract model. Note that the tests reported in Taylor (1980b) mentioned in Section 4 above compared price levels rather than rates of inflation; hence, the reason for one test passing and the other failing.

To remedy this problem Fuhrer and Moore (1995a, 1995b) modified the staggered contract model. Rather than current price levels being based on expected future price levels as in the standard staggered contract models, their modified model has current price inflation being based on expected future price inflation. The replacement of levels by rates of change generated a model with inflation persistence rather than simply price level persistence. However, the theoretical foundations of the staggered contract model are based on levels not rates of change (recall the discussion of the derivation by Akerlof and Yellen (1988) above).

To be sure, Fuhrer and Moore motivated their alternative formulation by restating the price decision in "real" terms. To see this most simply, set $\gamma=\varepsilon_{\mathrm{t}}=0$ and replace rational expectations by perfect foresight in equation (4-2). Note that after substitution from equation (4-1) we get: 


$$
x_{t}=.5\left(x_{t-1}+x_{t+1}\right)
$$

which illustrates how the current contract price depends on future and lagged contract prices. Now suppose that rather than using $x_{t}$ in equation (6-1) we formulate the price decision in terms of $x_{t}$ $\mathrm{p}_{\mathrm{t}}$, which looks like a "real" price: the current $(\log )$ contract price is deflated by the $(\log )$ aggregate price. Replacing $x_{t+d}$ with $x_{t+s}-p_{t+s}$ for $s=0,1$ and -1 , in equation (6-1), we get (after some algebraic manipulation)

$$
\Delta \mathrm{x}_{t}=.5\left(\mathrm{x}_{\mathrm{t}-1}+\Delta \mathrm{x}_{\mathrm{t+1}}\right)
$$

where $\Delta x_{t}=x_{t}-x_{t-1}$. Thus, all the properties stated above in terms of price levels are now restated in terms of the inflation rate. However, this definition of the real price effectively deflates by a price that does not apply to the full period ( $t$ and $t+1$ ) of the contract price; that is, $p_{t}$ applies to only $1 / 2$ of the period that $x_{t}$ applies to. In fact, if one replaces $x_{t}$ in equation (6-2) with $x_{t}-.5\left(p_{t}+p_{t+1}\right)$, which may seem like a more appropriate real price, then the model remains in level form, and equation (6-1) reappears. Thus, while the Fuhrer-Moore formulation may work in macroeconomic empirical applications, it leaves puzzles about the microfoundations.

Rotemberg (1997), in commenting on Fuhrer (1997), 
argues that there is nothing wrong with appealing to other sources of persistence of inflation within the staggered contracting approach. It is possible, of course, that inflation persistence could be due to serial correlation of money, but since one of the aims of these models is to explain persistence, leaving all the persistence of inflation to exogenous serial correlation is not a completely satisfactory conclusion either.

In a recent paper Roberts (1996) reexamines Fuhrer and Moore's (1995a, 1995b) findings. By exploring alternative expectations formation mechanisms, Roberts (1996) demonstrates that a small amount of "imperfect information" about the determinants of inflation when combined with staggered price setting is enough to explain the observed serial correlation of inflation. In my view, Robert's (1996) results indicate why it is likely that a full understanding of price and wage rigidities will eventually involve both imperfect information and staggered contracts of some form. Gertler $(1981,1982)$ developed a model of wage rigidities and wage inertia that is based on imperfect information. Rudin (1987) developed a formal model of staggered price setting in which there are diverse expectations on the part of firms giving rise to a situation where firms' expectations depend on other firms' expectations, and so on. 


\subsection{Real Output Persistence}

The recent study by Chari, Kehoe, and McGrattan (1998) emphasizes another potential persistence problem with the staggered price and wage setting model. Their study and the responses it has stimulated nicely illustrate the potential benefits of using dynamic optimizing models to study wage and price stickiness. As mentioned above, Chari, Kehoe, and McGrattan (1996) place a staggered contracts mechanism into an optimizing model in which price setting rules are derived assuming monopolistic competition; they assume that money is in the utility function. They then examine the dynamic properties of the model and compare the properties with the staggered contract mechanism when placed in a model with less formal optimization; that is, with equations (4-1) and (4-2) above. Through a pairwise comparison of the models, they find that, with reasonable parameter values calibrating the optimizing model, they cannot get coefficients on the staggered price setting equations that are large enough to generate empirically realistic serial correlation; they find virtually no persistence beyond the length of the longest contract. In terms of equation (4-2), the value of $\gamma$ they get from their calibration exercise is much too large. Hence, the persistence is much shorter than the kind of persistence that West (1988), Blanchard (1990), and Phaneuf (1990) have found with the staggered contract model. Ascari 
(1998) develops an optimizing model of staggered wage setting which also implies that the $\gamma$ parameter is way too large.

Several interesting papers have already been written in reaction to the findings of Chari, Kehoe and McGrattan (1998). Gust (1998) shows that restricting capital mobility between sectors can increase persistence in the Chari, Kehoe, McGrattan (1998) model. Kiley (1997) and Jeanne (1998) show that increasing the size of real rigidities (in the sense of Ball and Romer (1995)) can increase persistence in the model. A common theme of these papers is that there needs to be some neighborhood effects between price setters, so that one firm pays close attention to the price decision of the next firm and the most recent firm, thereby linking the price decision of one firm to another and causing the persistence effects. Gust's (1998) model illustrates this by tracing out in detail the effects of shocks with and without capital mobility; in his model capital plays a role in affecting the linkage between price decisions in different markets.

The Chari, Kehoe, and McGrattan (1998) model assumes complete wage flexibility. Alternatively, Erceg (1997) shows how including staggered wage setting along with staggered price setting increases persistence and enables a calibrated optimizing model with staggered contracts to generate the persistence observed in the data. Bergen and Feenstra (1998) introduce a more general functional form for the demand curve facing the 
monopolistic competitors, which leads to a lower value for $\gamma$. The effect of the constant elasticity demand functions on persistence is also noted by Kimball (1995).

It is also important to note that Rotemberg and Woodford (1998) and King and Wolman (1998) in a similar type of modeling framework find long persistence of monetary shocks with relatively short price contracts. Rotemberg and Woodford (1998) assume price setting equations which are geometric after a time delay, thereby coming close to the microeconomic empirical estimates discussed in Section 2 where the most common length of price contracts seems to be about three or four quarters. Rotemberg and Woodford (1998) conclude that their model generates realistic macroeconomic persistence of money shocks. King and Wolman (1998) assume two period contracts and also generate realistic macroeconomic persistence.

Another possible resolution of the Chari, Kehoe, McGrattan persistence puzzle is that the monopolistic competition model used to derive the price adjustment equation may not be adequate. Recall that Deborah Lucas $(1985,1986)$ used a competitive contracting mechanism to derive the price rule (actually a wage rule), and found that the impacts of shocks were quite persistent. The inconsistency pointed out in the Chari, Kehoe, and McGrattan (1998) study raises issues about monopolistically competitive pricing that need to be investigated 
further. As Arrow (1959) argued, the market power a firm has when setting its price is temporary and may be quite different than the market power in a full monopolistic competition model. If so, then it is a mistake to tie the price adjustment parameter $\gamma$ to demand elasticity parameters. As mentioned in the discussion following equation (4-1) above, prices may be responding to excess demand and not simply be moving along a demand curve as is assumed in the monopolistic model of price setting. Thus, the findings of Chari, Kehoe, McGrattan (1998) may indicate that the monopolistic competition (stationary market power) model may not be sufficient as a microeconomic foundation.

\subsection{Changes in Stability and Nominal Rigidity over Time}

One of the great historical puzzles in monetary economics is why economic fluctuations are smaller now than they were before the World War II. Part of the explanation has been that economic shocks are smaller, perhaps because of better monetary and fiscal policy or perhaps because of other changes in the economy such as dividend policy at firms.

Using the staggered contracts model in equations (4-1) and (4-2), DeLong and Summers (1986) argued that the improved economic performance was the result of a greater degree of price and wage rigidity in the economy. On the other hand, Taylor (1985) argued just the opposite using the same 
model, but calibrating the average size of the price shocks compared to the average size of the demand shocks: if price shocks are large enough, then greater price and wage rigidity would increase instability because it takes larger swings in real output and employment to offset price shocks. Other explanations for the increased economic stability--such as dividend policy or monetary policy changes-would therefore be needed.

As shown in Driskill and Sheffrin (1986) the different views do in fact boil down to whether demand shocks or price shocks are more important. They show analytically that if price shocks are more important, then less rigidity of prices would lead to greater output stability.

\section{Concluding Remarks on Policy Applications and Future Research}

One of the most important reasons to develop detailed models of wage and price rigidities that explain the effects of money on the economy is to conduct monetary policy evaluation research. Such policy applications are an appropriate place to conclude this survey for they suggest where future research may be going.

Econometric evaluation of monetary policy is now wellestablished and increasingly used in policy research. The most 
common strategy is to build and estimate a dynamic econometric model of the economy and then simulate that model with alternative feedback rules for monetary policy. Among the alternative rules, the policy which leads to the best, or at least a reasonably good, outcome is the optimal policy, and presumably the one recommended to policymakers. The general approach was developed by Lucas (1976) building on work by Marshak (1953) and others at the Cowles Commission where the need for structural econometric models for policy was a major motivation for the development of simultaneous equation methods.

Improvements in rational expectations solution algorithms and estimation techniques have made it possible to perform such policy evaluations in large scale non-linear systems, in which stochastic simulations are essential. Without these newly developed algorithms, the large number of required replications would not be feasible.

Examples of the use of econometric models for policy evaluation include Taylor (1979a) and McCallum (1988) which have focussed on small models. In Taylor (1979a) I derived an optimal feedback rule for the money supply in a rational expectations model with staggered price setting. McCallum (1988) simulated policy rules for several different models, including nonstructural models. This research is summarized in the chapter by McCallum (1998) in this Handbook. 
More recently it has been possible to carry out such policy simulation exercises in large scale open economy models. These international models incorporate uncovered interest rate parity assumptions as in the Mundell and Fleming framework as well as staggered price and wage setting, following the lead of Dornbusch (1982). For example, in Taylor (1993a) a multicountry model with rational expectations and staggered wage setting was used to search for good interest rate and/or exchange rate policy rules. Comparative simulations of several other large scale models--many within the rational expectations, staggered price and wage setting framework--are presented in Bryant, Hooper and Mann (1993). Using these results I suggested a policy rule for monetary policy (Taylor (1993b)), which has been useful for practical monetary policy discussions, illustrating the usefulness of this whole approach to policy.

The Federal Reserve Board has developed and started using a new econometric model which incorporates both rational expectations and a form of staggered wage and price setting. As described by Brayton, Tryon, Levin, and Williams (1997) the model is used mostly for policy evaluation, including the evaluation of monetary policy rules.

More recently researchers such as Rotemberg and Woodford (1998) and King and Wolman (1998) have begun to use estimated or calibrated general equilibrium optimizing models 
with staggered price setting to evaluate alternative monetary policy rules. Further developments along these lines are bound to be interesting and useful in policy work. For example, what are the policy implications of combining time-dependent pricing with state-dependent pricing as in Dotsey, King and Wolman (1996)?

An important advantage of the newer models that include both utility maximization and staggered price setting is that monetary policy can be evaluated using the standard tools of public finance. Welfare measures such as compensating variations or equivalent variations thus replace cruder quadratic loss functions in terms of aggregate output or inflation. Rotemberg and Woodford (1998) evaluate the effect of different monetary policy rules using the welfare function of the representative agents in their model. They find that the parameters of the staggered price setting equations in their model have a significant effect on their welfare calculations.

In sum, the form, interpretation, and parameter values of staggered price and wage setting models are highly relevant not only for explaining the impact of monetary policy, but also for evaluating its welfare consequences. Understanding these models more thoroughly takes one well beyond macroeconomics into the heart of the price discovery and adjustment process in competitive and imperfectly competitive markets. Further 
research on the empirical robustness and microeconomic accuracy of staggered contracts models is thus both interesting and practically important. 


\section{REFERENCES}

Abraham, Jesse (1987), Income redistribution during a disinflation, Journal of Macroeconomics, 9:203 221.

Akerlof, George A. and Janet L. Yellen (1991), How large are the losses from rules of thumb behavior in models of the business cycle, in William Brainard, William Nordhaus, and Harold Watts (Eds.), Money, Macroeconomics, and Economic Policy: Essays in Honor of James Tobin. (MIT Press, Cambrideg Mass).

Arrow, Kenneth (1959), Toward a theory of price adjustment, in Moses Abramovitz et al., The Allocation of Economic

Resources: Essays in Honor of Bernard Francis Haley, (Stanford University Press, Stanford, California).

Ascari, Guido (1998), Optimizing agents, staggered wages and persistence in the real effects of money shocks, unpublished paper, University of Warwick.

Ashenfelter, Orley and David Card, Time series representations of economic variables and alternative models of the labor market, Review of Economic Studies, 49:761 781.

Azariadis, Costas (1975), Implicit contracts and nderemployment equilibria, Journal of Political Economy, 83:1183 1202.

Backus, David (1984), Exchange rate dynamics in a model with staggered wage contracts, Queens University, Discussion Paper No. 561, June.

Ball, Laurence (1987), Externalities from contract length, American Economic Review, 77:615 629.

Ball, Laurence (1994), Credible disinflation with staggered price 
setting, American Economic Review, 84:282 289.

Ball, Laurence and Stephen Cecchetti (1988), Imperfect information and staggered pricing, American Economic Review, 78:999 1018.

Ball, Laurence, N. Gregory Mankiw, and D. Romer (1988), The new Keynesian economics and the output-inflation tradeoff, Brookings Papers on Economic Activity, 1:1 65.

Ball, Laurence and David Romer, (1989), The equilibrium and optimal timing of price changes, Review of Economic Studies, 56:179 198 .

Ball, Laurence and David Romer (1990), Real rigidities and the nonneutrality of money, Review of Economic Studies, 57:183 203.

Barro, Robert J. (1977), Unanticipated money growth and unemployment in the United States, American Economic Review, 67:101 115 .

Barro, Robert J. and Hercowitz, Zvi (1980), Money stock revisions and unanticipated money growth, Journal of Monetary Economics, 6: 257267.

Benabou, Roland and Claude Bismut (1987), Wage bargaining and staggered contracts: theory and estimation, Discussion Paper No. 8810, CEPREMAP, Paris, France.

Bergen, Paul R. and Robert C. Feenstra (1998), Staggered price setting and endogenous persistence, NBER Working paper, No. 6429.

Bernanke, Ben S., Mark Gertler, and Simon Gilchrist (1998), 
Credit market frictions and cyclical fluctuations, in John B.

Taylor and Michael Woodford (Eds.), Handbook of

Macroeconomics, (North-Holland, Amsterdam).

Bhaskar, V. (1998), On endogenously staggered prices,

University of St. Andrews, Discussion Paper Series, No, 9806,

St. Andrews, Scotland.

Blanchard, Olivier J. (1983), Price asynchronization and price level inertia, in R. Dombush and M. Simonsen (Eds.), Inflation Debt, and Indexation, (MIT Press, Cambridge), 324.

Blanchard, Olivier J. (1987), Aggregate and individual price adjustment, Brookings Papers on Economic Activity, 1:57 122.

Blanchard, Olivier (1990), Why does money affect output? A survey, in B. Friedman and F. Hahn (Eds), Handbook of Monetary Economics, (Amsterdam, North Holland).

Blanchard, Olivier and Stanley Fischer (1989), Lectures on Macroeconomics, (MIT Press, Cambridge, Massachusetts).

Blanchard, Olivier and Nobuhiru Kiyotaki (1987), Monopolistic competition and the effects of aggregate demand, American Economic Review, 77:647 666.

Blinder, Alan (1994), On sticky prices: academic theories meet the real world, in N. Gregory Mankiw, (Ed.), Monetary Policy, (University of Chicago Press, Chicago), 117150.

Blinder, Alan, Edie D. Canetti, David E. Lebow, and Jeremy B. Rudd (1998), Asking about prices: a new approach to understanding price stickiness, (Russell Sage Foundation: New York). 
Brayton, Flint, Andrew Levin, Ralph Tryon, and John Williams (1997), The evolution of macro models at the Federal Reserve Board, B. McCallum and C. Plosser (Eds.), Carnegie Rochester Conference Series on Public Policy, 47:43 81

Brunner, Karl, Alex Cukierman, and Allan Meltzer (1980), Stagflation, persistent unemployment, and the permanence of shocks, Journal of Monetary Economics, 6:467 492.

Bryant, Ralph, Peter Hooper, and Catherine Mann (1993), Evaluating Policy Regimes: New Empirical Research in Empirical Macroeconomics, (Brookings Institution, Washington D.C.).

Buckle, Robert A. and John A. Carlson (1995), Price duration with two-sided pricing rules, Karl Heinrich Oppenlanderand, Gunter Poser (Eds), Business Cycle Surveys: Forecasting Issues and Methodological Aspects, (Avebury: Aldershot), 99118.

Buiter, Willem and Ian Jewitt (1981), Staggered wage setting with real wage relatives: variations on a theme of Taylor, The Manchester School, 47.

Caballero, Ricardo and Eduardo Engel (1993), Microeconomic rigidities and aggregate price dynamics, European Economic Review, 37:691711

Calvo, Guillermo (1982), Staggered contracts and exchange rate policy, in J.A. Frankel (Ed.), Exchange Rates and International Macroeconomics, (University of Chicago Press, Chicago).

Calvo, Guillermo (1983), Staggered prices in a utility maximizing framework, Journal of Monetary Economics, 12: 3 398. 
Caplin, Andrew S. and Daniel Spulber (1987), Menu costs and the neutrality of money, Quarterly Journal of Economics, 102: 703725 .

Card, David and Dean Hyslop (1997), Does inflation "grease the wheels of the labor market"? in Christina Romer and David Romer (Eds.), Reducing Inflation, (University of Chicago Press, Chicago), 71114.

Carlton, Dennis W. (1986), The rigidity of prices, American Economic Review, 76: 637658.

Carlton, Dennis (1989), The theory and the facts of how markets clear: is industrial organization valuable for understanding macroeconomics? in Schmalensee, R. and Robert D. Willig (Eds.), Handbook of Industrial Organization, (North-Holland, Amsterdam) 1:909 946.

Cecchetti, Stephen G. (1983), Staggered contracts and the frequency of price adjustment, Quarterly Joumal of Economics, 100: 935959.

Cecchetti, Stephen G. (1984), Indexation and incomes policy: a study of wage adjustment in unionized manufacturing, Journal of Labor Economics, 5:391 412.

Cecchetti, Stephen G. (1986), The frequency of price adjustment: a study of newstand prices of magazines, Journal of Econometrics, 31: 255274.

Chadha, Binky (1987), Is increased price inflexibility stabilizing? Journal of Money Credit and Banking, 21:481 497.

Chari, V.V., Patrick Kehoe and Ellen McGrattan (1998), Sticky price models of the business cycle: can the contract multiplier 
solve the persistence problem? Federal Reserve Bank of Minneapolis, Research Department Staff Report No. 217, revised April 1998.

Cho, Jang Ok (1993), Money and business cycles with one period nominal contracts, Canadian Journal of Economics, 26:638 659.

Cho, Jang Ok, and Thomas F. Cooley (1995), The business cycle with nominal contracts, Economic Theory, 6:13 33.

Christiano, Lawrence J. (1985), A method for estimating the timing interval in a linear econometric model, with application to Taylor's model of staggered contracts, Journal of Economic Dynamics and Control, 9:363 404.

Christiano, Lawrence, Martin Eichenbaum, and Charles Evans (1998), Monetary policy shocks: what have we learned and to what end?, in John B. Taylor and Michael Woodford (Eds.), Handbook of Macroeconomics, (North Holland, Amsterdam).

Conlon, John R. and Christina Y. Liu (1997), Can more frequent price changes lead to price inertia? Nonneutralities in a statedependent pricing context, International Economic Review, 38:893 914.

Davis, Douglas and Charles A. Holt (1997), Price rigidities and institutional variation in markets with posted prices, Economic Theory, 9:63 80 .

De Fraja, Giovanni (1993), Staggered versus synchronized wage setting in oligopoly, European Economic Review, 37:1507 1522.

De Long, J. Bradford and Lawrence Summers (1986), Is increased price flexibility stabilizing? American Economic Review, 78:1031 1044. 
Dezhbakhsh, Hashem, Alfred A. Haug, J. Huston McCulloch, Gajendra S. Poonia and Le-Tuan Wang (1984), The statistical Phillips Curve in Taylor's staggered contracts model, Unpublished Paper.

Domberger, Simon and Denzil G. Fiebig (1993), The distribution of price changes in oligopoly, The Joumal of Industrial Economics, 41:295 313 .

Domowitz, I., Hubbard, R.G. and B.C. Peterson (1986), Business cycles and the relationship between concentration and price-cost margins, Rand Journal of Economics, Vol. 17:1 17.

Dormbusch, Rudiger (1982), PPP exchange rate rules and macroeconomic stability, Journal of Political Economy, 90:158 165 .

Dotsey, Michael, Robert G. King and Alexander L. Wolman (1996), State dependent pricing and the dynamics of business cycles, unpublished paper.

Driskill Robert A. and Steven M. Sheffrin (1986), Is price flexibility destabilizing? American Economic Review, 76:802 807.

Dutta, Shantanu, Mark Bergen and Daniel Levy (1997), Price flexibility in channels of distribution: evidence from scanner data," unpublished paper, September 14, 1997, Emory University.

Eden, Benjamin (1994a), Time rigidities in the adjustment of price to monetary shocks: an analysis of micro data, Discussion paper, No 94.16, Bank of Israel. 
Eden, Benjamin (1994b), The adjustment of prices to monetary shocks when trade is uncertain and sequential, Journal of Political Economy, 102:493 409.

Evans, George and Seppo Honkapohja (1998), Learning Dynamics, in John B. Taylor and Michael Woodford (Eds.), Handbook of Macroeconomics, (North-Holland, Amsterdam).

Erceg, Christopher (1997), Nominal wage rigidities and the propagation of monetary disturbances, unpublished paper, Federal Reserve Board.

Fethke, Gary and Andrew Policano (1984), Wage contingencies, the patterns of negotiation and aggregate implications of alternative contract structures, Journal of Monetary Economics, 14:151 170 .

Fethke, Gary and Andrew Policano (1986), Will wage setters ever stagger decisions? Quarterly Journal of Economics, 101:867 877.

Fethke, Gary and Andrew Policiano (1987), Monetary policy and the timing of wage negotiations, Journal of Monetary Economics, 19:87 105 .

Fischer, Stanley (1977), Long-term contracts, rational expectations, and the optimal money supply rule, Journal of Political Economy, 85:191 205.

Fregert, Klas and Lars Jonung (1986), Monetary regimes and the length of wage contracts, paper presented at the 1986 Konstanz Conference.

Friedman, Milton (1982), Column, p. 64, Newsweek, July 12, 1982. 
Fuhrer, Jeffrey (1997), Towards a compact, empirically-verified rational expectations model for monetary policy analysis, in $\mathrm{B}$. McCallum and C. Plosser (Eds.), Camegie Rochester Conference on Public Policy, (North-Holland, Amsterdam), 47:197 231.

Fuhrer, Jeffrey and George Moore (1995a), Monetary policy tradeoffs and the correlation between nominal interest rates and real output, American Economic Review, 85:219 239.

Fuhrer, Jeffrey and George Moore, (1995b), Inflation persistence, Quarterly Journal of Economics, 110:127 159.

Gertler, Mark (1981), Long-term contracts, imperfect information, and monetary policy, Journal of Economic Dynamics and Control, 3:197 216.

Gertler, Mark (1982), Imperfect information and wage inertia in the business cycle, Journal of Political Economy, 90:967 987.

Gordon, Robert (1981), Output fluctuations and gradual price adjustment, Journal of Economic Literature, 19:493 530.

Goodfriend, Marvin and Robert King (1997), The new neoclassical synthesis and the role of monetary policy, in Ben Bernanke and Julio Rotemberg (Eds.), NBER Macroeconomics Annual, (MIT Press, Cambridge Massachusetts), 493530.

Gray, Jo Anna (1976), Wage indexation: a macroeconomic approach, Journal of Monetary Economics, 2:221 235.

Gray, Jo Anna (1978), On indexation and contract length, Journal of Political Economy, 86:1 18.

Gust, Christopher (1997), Staggered price contracts and factor 
immobilities: the persistence problem revisited, unpublished paper, Northwestern University.

Hairault, Jean-Olivier and Franck Portier (1993), Money, new Keynesian macroeconomics, and the business cycle, European Economic Review, 37:15331568.

Ireland, Peter N. (1996), A small structural quarterly model for monetary policy evaluation, Carnegie Rochester Conference on Public Policy, (North Holland, Amsterdam), 47:83 108.

Jeanne, Olivier (1997), Generating real persistent effects of monetary shocks: how much nominal rigidity do we really need? NBER Working Paper No. 6258.

Kashyup, Anil K. (1995), Sticky prices: new evidence from retail catalogues, Quarterly Journal of Economics, 110:245 274.

Kiley, Michael T. (1997), Staggered price setting, partial adjustment, real rigidities, and sunspots, unpublished paper, Federal Reserve Board.

Kim, J. (1995), Monetary Policy in a stochastic equilibrium model with real and nominal rigidities, unpublished paper, Yale University.

Kimball, Miles S. (1995), The quantitative analysis of the basic neomonetarist model, Journal of Money Credit and Banking, 27:1241 1277 .

King, Robert G. and Alexander L. Wolman (1996), Inflation targeting in a St. Louis model of the 21 st century, Federal Reserve Bank of St. Louis Review, 78:93 107

King, Robert G. and Alex Wolman (1998), What should the monetary authority do when prices are sticky, in John B. Taylor 
(Ed.), Monetary Policy Rules, (University of Chicago Press, Chicago).

Lach, Saul and Daniel Tsiddon (1992), The behavior of prices and inflation: an empirical analysis of disaggregated data, Journal of Political Economy, 100:349 389.

Lach, Saul and Daniel Tsiddon (1996), Staggering and synchronization in price-setting: evidence from multiproduct firms, American Economic Review, December, 86:1175 1196.

Lau, Sau-Him Paul (1996), Aggregate pattern of time-dependent adjustment rules I: a game-theoretic analysis of staggered versus synchronized wage setting, Economic Journal, 106:1645 1658.

Lau, Sau-Him Paul (1997), Aggregate pattern of time-dependent adjustment rules II: strategic complementary and endogenous nonsynchronization, The Australian National University, Working Papers in Economics and Econometrics, No. 317 January.

Lebow, David, David Stockton and William Wascher (1995), Inflation, nominal wage rigidity and the efficiency of labor markets, unpublished paper, Federal Reserve Board.

Leeper, Eric and Christopher Sims (1994), Toward a modern macroeconomic model usable for policy analysis, in S. Fischer and J. Rotemberg (Eds.), NBER Macroeconomics Annual, (MIT Press, Cambridge), 81118.

Levin, Andrew (1989), The theoretical and empirical relevance of staggered wage contract models, Ph.D. dissertation, Stanford University.

Levin, Andrew (1990), Monetary stabilization policy in a general 
equilibrium model with wage contracts, University of California at San Diego, Working Paper No. 90-43, December.

Levin, Andrew (1991), The macroeconomic significance of nominal wage contract duration, University of California at San Diego Working Paper No. 91-08, February.

Levy, Daniel, Mark Bergen, Shantanu Dutta, Robert Venable (1997), The magnitude of menu costs: direct evidence from large U.S. supermarket chains, Quarterly Journal of Economics, 114:791825.

Levy, Daniel, Shantanu Dutta, Mark Bergen, Robert Venable (1998), Price adjustment at multiproduct retailers, Managerial and Decision Economics, forthcoming.

Lucas, Deborah (1985), Price and interest rate dynamics induced by multiperiod contracts, Northwestern University, Working Paper.

Lucas, Deborah (1986), Rigid wages as a transmission mechanism for monetary shocks, Northwestern University, Working Paper.

Lucas, Robert E. Jr. (1972), Expectations and the neutrality of money, Journal of Economic Theory, 4:103 124.

Lucas, Robert E. Jr. (1973), Some international evidence on output inflation tradeoffs, American Economic Review, 63:326 334.

Lucas, Robert E. Jr. (1976), Econometric policy evaluation: a critique, Carnegie Rochester Conference Series on Public Policy, $1: 1946$. 
Lucas, Robert E. Jr. (1996), Nobel lecture: monetary neutrality, Journal of Political Economy, 104:661 682.

Lucas, Robert E. Jr. and Michael Woodford (1994), Real effects of monetary shocks in an economy with sequential purchases, NBER Working Paper No. 4250.

Marchak, Jacob (1953), Economic measurement for policy and prediction, studies in econometric method, Cowles Commission for Research in Economics, Monograph No.14, New Haven: Yale University Press.

Matsukawa, Shigeru (1986), The equilibrium distribution of wage settlements and economic stability, International Economic Review, 27:415 437 .

McCallum, Bennett (1982), Macroeconomics after a decade of rational expectations: some critical issues, Federal Reserve Bank of Richmond Economic Review, 68:3 12.

McCallum, Bennett (1984), A linearized version of Lucas's neutrality model, Canadian Journal of Economics, 17:138 145.

McCallum, Bennett (1988), Robustness properties of a rule for monetary policy, Camegie Rochester Conference on Public Policy, 29:173 203.

McCallum, Bennett (1998), Issues in the design of monetary policy rules, in John B. Taylor and Michael Woodford (Eds), Handbook of Macroeconomics, (North-Holland, Amsterdam).

McLaughlin, Kenneth J. (1994), Rigid wages? Journal of Monetary Economics, 34:383 414.

Montgomery, Edward (1983), A note on aggregate dynamics and 
staggered contracts: a test of the importance of spillover effects, Working Paper No. 82-6, Camegie Mellon School of Urban and Public Affairs.

Mishkin, Fredric S. (1982), Does anticipated monetary policy matter? an econometric investigation, Journal of Political Economy, 90:22 51.

Nelson, Edward (1997), A framework for analyzing alternative models of nominal rigidities, unpublished paper, Carnegie Mellon University.

Ohanian, Lee E. and Alan C. Stockman (1994), Short run effects of money when some prices are sticky, Federal Reserve Bank of Richmond Economic Review, 80:1 23.

Okun, Arthur M. (1981), Prices and Quantities: A Macroeconomic Analysis, Brookings Institution, Washington D.C.

Parkin, Michael (1986), The output-inflation tradeoff when prices are costly to change, Journal of Political Economy, 94:200 224.

Phaneuf, Louis (1987a), Can contract-based models explain business cycles?, University of Montreal Working Paper.

Phaneuf, Louis (1987b), Proprietes dynamics des modeles du cycle a contrats echleonnes, Canadian Journal of Economics, 20: 123139.

Phaneuf, Louis (1990), Wage contracts and the unit root hypothesis, Canadian Journal of Economics, 23:580 592.

Phelps, Edmund (1978), Disinflation without recession: adaptive 
guideposts and monetary policy, Weltwirtschaftliches Archiv, 114: 783809 .

Phelps, Edmund and Taylor, John B. (1977), Stabilizing powers of monetary policy under rational expectations, Journal of Political Economy, 85:163 190.

Poterba, James M., Julio J. Rotemberg, and Lawrence $H$. Summers (1986), A tax-based test for nominal rigidities, American Economic Review, 76:659 675.

Prescott, Edward C. (1975), Efficiency of the Natural Rate, Journal of Political Economy, 83:1229 1236.

Rankin, N. (1998), Nominal rigidity and monetary uncertainty, European Economic Review, 42:185 199.

Rehm, Dawn E., Staggered contracts, capital flows and macroeconomic stability in the open economy, $\mathrm{Ph}$. D. dissertation Columbia University, 1983.

Roberts, John M. (1995), New Keynesian economics and the Phillips curve, Journal of Money Credit and Banking, 27:975 984.

Roberts, John M. (1997), Is inflation sticky? Journal of Monetary Economics, 39:173 196.

Romer, David (1996), Advanced Macroeconomics, (McGraw Hill, New York).

Rotemberg, Julio (1982), Sticky prices in the United States, Journal of Political Economy, 90:1187 1211.

Rotemberg, Julio (1987), The new Keynesian foundations, in 
Stanley Fischer (Ed.), NBER Macroeconomics Annual 1987, (The MIT Press, Cambridge, Massachusetts), 69104.

Rotemberg, Julio (1997), A comment, in B. McCallum and C. Plosser (Eds.), Camegie Rochester Conference Series of Public Policy, (North-Holland, Amsterdam) 47:231 243.

Rotemberg, Julio and Michael Woodford (1997), An optimization-based econometric framework for the evaluation of monetary policy, in Ben Bernanke and Julio Rotemberg (Eds.), NBER Macroeconomics Annual, (MIT Press, Cambridge, Massachusetts).

Rotemberg, Julio and Michael Woodford (1998), The cyclical behavior of prices and costs, in John B. Taylor and Michael Woodford (Eds.), Handbook of Macroeconomics, NorthHolland, Amsterdam).

Rotwein, E. (Ed.), (1955), David Hume's Writings on Economics, (University of Wisconsin Press, Madison, Wisconsin).

Rudin, Jeremy (1987), Diverse expectations in an empirical model: an extension of the staggered contracts model, Chapter 2 of Diverse Expectations: Policy and Empirical Implications Ph.D. Dissertation, Stanford University.

Sargent, Thomas J. (1976), A classical macroeconomic model for the United States, Journal of Political Economy, 84:207 237.

Sargent, Thomas J, and Neil Wallace (1975), 'Rational' expectations, the optimal monetary instrument, and the optimal money supply rule, Journal of Political Economy, 83:241-254.

Sheshinski, Eytan and Yoram Weiss (1988), Staggered and 
synchronized price polices and multiproduct monopolies, TelAviv, Foerder Institute for Economic Research, Working Paper No. 24-78, July.

Slade, Margaret E. (1996), Optimal pricing with costly adjustment: evidence from retail-grocery prices, unpublished paper, University of British Columbia.

Stigler, George and James Kindahl (1970), The Behavior of Industrial Prices, NBER General Series, No. 90, New York: Columbia University Press.

Stock, James and Mark Watson (1998), Business cycle fluctuations in U.S. macroeconomic time series, in John B. Taylor and Michael Woodford (Eds.), Handbook of Macroeconomics, (North Holland, Amsterdam).

Svensson, Lars E.O. (1986), Sticky goods prices, flexible asset prices, monopolistic competition, and monetary policy, Review of Economic Studies, 52:385 405.

Taylor, John B. (1975), Monetary policy during a transition to rational expectations, Journal of Political Economy, 83:1009 1021.

Taylor, John B. (1979a), Estimation and control of an econometric model with rational expectations, Econometrica 47:1267 1286 .

Taylor, John B. (1979b), An econometric business cycle model with rational expectations: some estimation results, unpublished Columbia University Working Paper, condensed version reprinted in chapter 2 of Taylor (1993a).

Taylor, John B. (1980a), Aggregate dynamics and staggered 
contracts, Journal of Political Economy, 88:1 22.

Taylor, John B. (1980b), Output and price stability: an international comparison, Journal of Economic Dynamics and Control, 2:109 132 .

Taylor, John B. (1983), Union wage settlements during a disinflation, American Economic Review, 73:981 993.

Taylor, John B. (1985), Rational expectations models in macroeconomics, in Kenneth Arrow and Seppo Honkapohja (Eds.), Frontiers of Economics, (Basil Blackwell, Oxford).

Taylor, John B. (1986), Improvements in macroeconomic stability: the role of wages and prices, in R.J. Gordon (Ed.), The American Business Cycle Continuity and Change, (University of Chicago Press, Chicago).

Taylor, John B. (1993a), Macroeconomic Policy in the World Economy: From Econometric Design to Practical Operation, (W.W. Norton, New York).

Taylor, John B. (1993b), Discretion versus policy rules in practice, Carnegie-Rochester Conference Series in Public Policy, 39:195 214

Tsiddon, D. (1991), On the stubborness of sticky prices, International Economic Review, 32:69 75.

Tsiddon, D. (1993), The (mis)behavior of the aggregate price level, Review of Economic Studies, 60:889 902.

Warner, Elizabeth J. and Robert Barsky (1995), The timing and magnitude of retail store markdowns: evidence from weekends and holidays, Quarterly Journal of Economics, 110:321 352. 
West, Kenneth (1988), On the interpretation of near random-walk behavior in GNP, American Economic Review, 78:202 209.

Woodford, Michael (1995), Comment on the quantitative analysis of the basic neomonetarist model, Journal of Money Credit and Banking, 27:1277 1284 .

Yun, Tack (1994), Monetary Policy, Nominal Price Rigidity and Business Cycles, Ph.D. dissertation, Department of Economics, University of Chicago.

Yun, Tack (1996), Nominal price rigidity, money supply endogeneity, and business cycles, Journal of Monetary Economics, 37:345 70 . 